\title{
Evaluation of Population Structure, Age, Growth, and Mortality of Blue Catfish and Flathead Catfish within the Robert C. Byrd Pool of the Ohio and Kanawha Rivers
}

Joseph Vincent Siegel

West Virginia University, jvs0010@mix.wvu.edu

Follow this and additional works at: https://researchrepository.wvu.edu/etd

Part of the Aquaculture and Fisheries Commons

\section{Recommended Citation}

Siegel, Joseph Vincent, "Evaluation of Population Structure, Age, Growth, and Mortality of Blue Catfish and Flathead Catfish within the Robert C. Byrd Pool of the Ohio and Kanawha Rivers" (2021). Graduate Theses, Dissertations, and Problem Reports. 8272.

https://researchrepository.wvu.edu/etd/8272

This Thesis is protected by copyright and/or related rights. It has been brought to you by the The Research Repository @ WVU with permission from the rights-holder(s). You are free to use this Thesis in any way that is permitted by the copyright and related rights legislation that applies to your use. For other uses you must obtain permission from the rights-holder(s) directly, unless additional rights are indicated by a Creative Commons license in the record and/ or on the work itself. This Thesis has been accepted for inclusion in WVU Graduate Theses, Dissertations, and Problem Reports collection by an authorized administrator of The Research Repository @ WVU. For more information, please contact researchrepository@mail.wvu.edu. 


\title{
EVALUATION OF POPULATION STRUCTURE, AGE, GROWTH, AND MORTALITY OF BLUE CATFISH AND FLATHEAD CATFISH WITHIN THE ROBERT C. BYRD \\ POOL OF THE OHIO AND KANAWHA RIVERS
}

\author{
J. Vincent Siegel \\ A thesis submitted to the \\ Davis College of Agriculture, Natural Resources, and Design \\ At West Virginia University
}

In partial fulfillment of the requirements for the degree of

Master of Science

in

Wildlife and Fisheries Resources

\author{
Stuart A. Welsh, Ph.D., Chair \\ Brent A. Murry, Ph.D. \\ Nate D. Taylor, M.S.
}

Division of Forestry and Natural Resources

\section{Morgantown, WV}

2021

Keywords: Ictalurus furcatus, Pylodictis olivaris, fisheries management 


\begin{abstract}
Evaluation of population structure, age, growth, and mortality of Blue Catfish and Flathead Catfish within the Robert C. Byrd Pool of the Ohio and Kanawha Rivers
\end{abstract}

\author{
J. Vincent Siegel
}

This thesis describes population characteristics of Blue Catfish Ictalurus furcatus and Flathead Catfish Pylodictis olivaris within the Robert C. Byrd Pool of the Ohio and Kanawha rivers. Three chapters are included as follows: 1) An introduction and literature review, 2) An assessment of the repatriation efforts of the Blue Catfish within the Robert C. Byrd Pool, and 3) A description of population data of Flathead Catfish within the Robert C. Byrd Pool. The Ohio River is continuing to recover from a long history of anthropogenic impacts. Blue Catfish were considered locally extirpated from the West Virginia sections and have been reintroduced through fingerling stockings beginning in 2002. Flathead Catfish are naturally sustaining in the pool and combined with Blue Catfish provide two popular recreational fisheries. The Blue Catfish and Flathead Catfish studies shared similar objectives: (1) evaluating size structure, (2) estimating growth rates, and (3) estimating annual mortality. From 2017 to 2020, we collected catfish annually through low frequency electrofishing and trotline surveys at 10 fixed locations. Electrofishing catch rates for Blue Catfish were poor, suggesting low densities. The presence of numerous sub-stock sized Blue Catfish supported natural reproduction. Electrofishing CPUE's for Flathead Catfish suggested a stable population with densities decreasing through the larger size classes. Trotline CPUE's demonstrated the trophy potential and gear bias for both species. Age analysis results supported variable recruitment in Blue Catfish. Back calculated hatch years of aged Blue Catfish pre- and post-dated stocking, providing evidence of a remnant population and further supporting natural reproduction. Blue Catfish growth was lower than expected for a newly reintroduced population. Flathead Catfish were long lived and slow growing with a maximum observed age of 34. Mortality estimates were low for both species suggesting low fishing mortality. The information provided from this study on population parameters could be useful for informing management decisions of Blue Catfish and Flathead Catfish fisheries in the Robert C. Byrd Pool. 


\section{ACKNOWLEDGEMENTS}

I would like to thank my advisor, Dr. Stuart Welsh, for giving me the opportunity to pursue a Master's in this amazing field. Your passion for ichthyology is infectious and is a constant source of inspiration. Your guidance, insights, and encouragement throughout my time here at WVU have been invaluable. I would like to thank Dr. Brent Murry for being on my committee. You have brought great perspectives to this study and have been wonderful to work with. I would like to thank Nate Taylor for your extensive role in this project, being on my committee, designing and securing funding for this project, for all the field work, time, and effort involved, creating this opportunity for me, and for being the best mentor and friend anyone could ask for.

I would like to thank Dr. Quinton Phelps for his assistance with the designing the project and Corbin Hilling for his technical knowledge and encouragement. I would like to thank all the WVDNR biologists and staff, who have been incredibly hospitable and supportive. You all have helped immensely with this project. I would like to thank Cory Hartman and Steve Hincks for your considerable contributions to the fieldwork for this study. I would like to thank the WVU undergraduates who assisted with this study, particularly Bethany Wager for the hours of otolith mounting and aging.

Lastly, I would like to thank my parents, friends, and family for their unwavering support.

I could not have done this without you all. 


\section{TABLE OF CONTENTS}

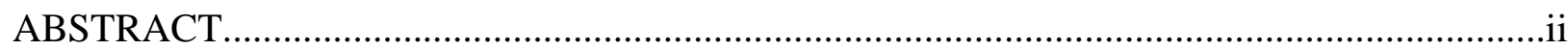

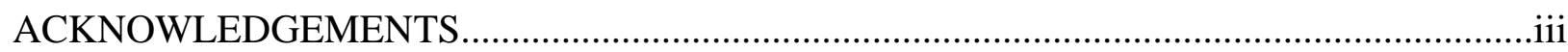

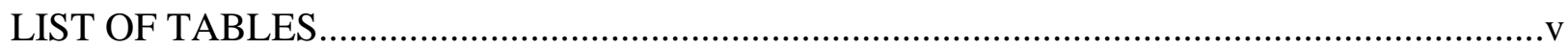

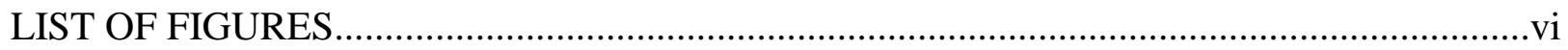

Chapter 1: Introduction and Literature Review............................................................ 1

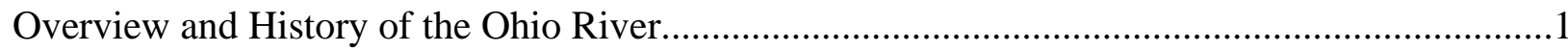

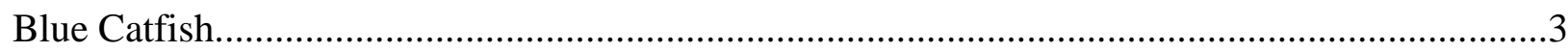

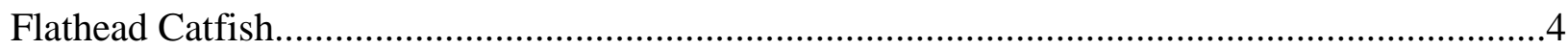

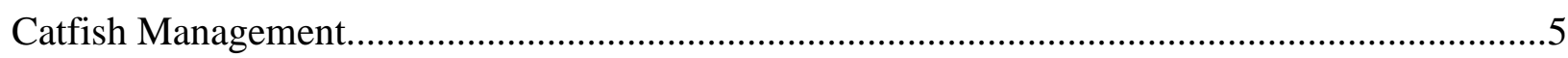

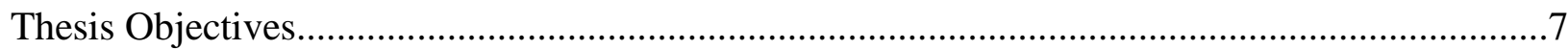

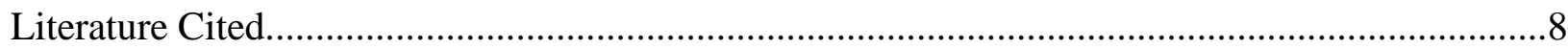

Chapter 2: Evaluation of a Recovering Blue Catfish Population within the middle Ohio and

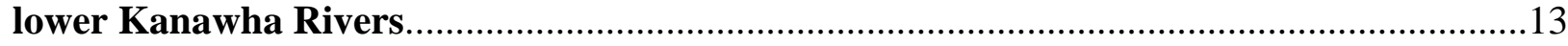

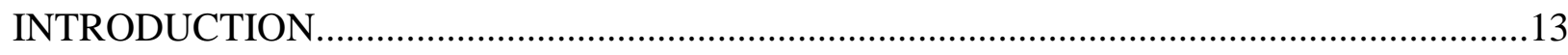

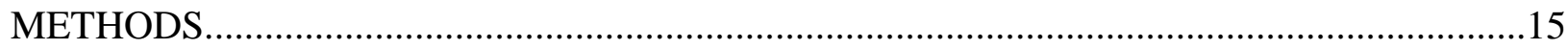

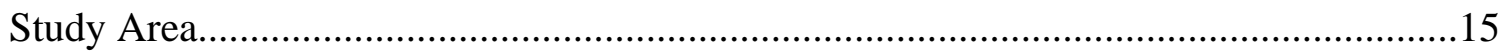

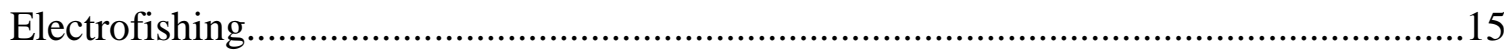

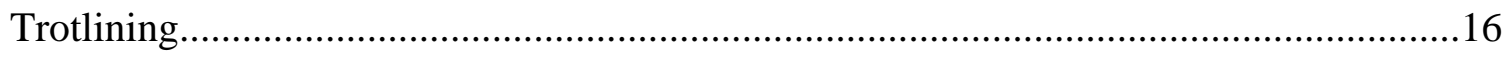

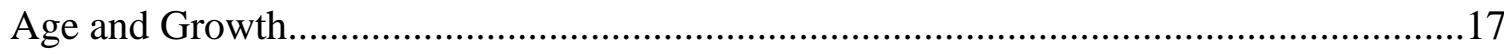

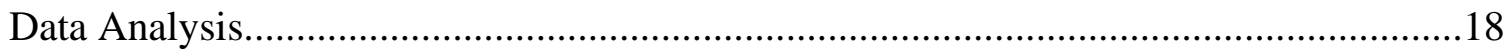

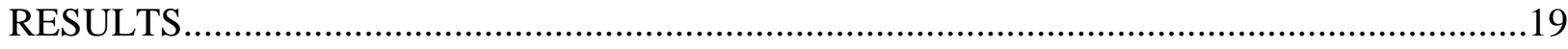

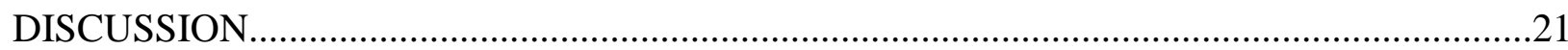

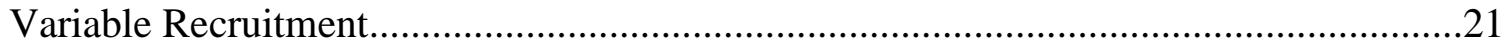

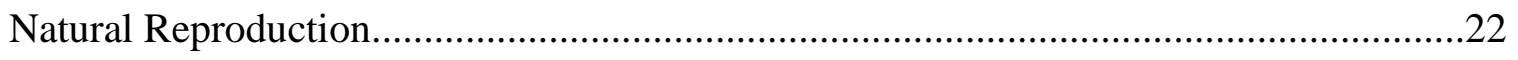

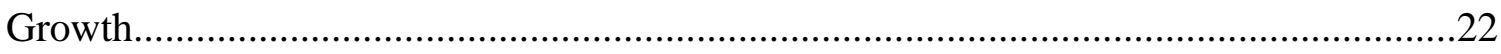

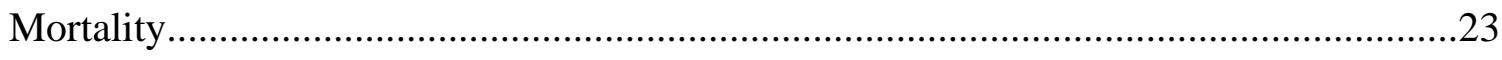

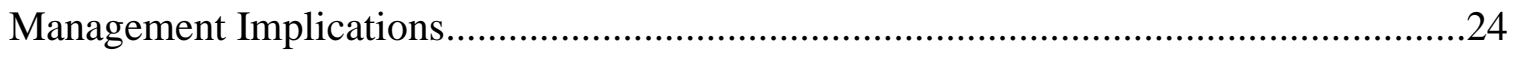




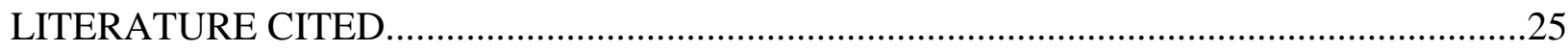

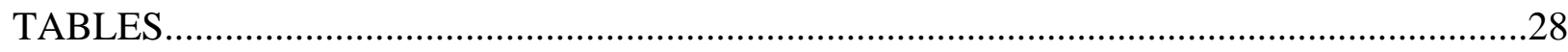

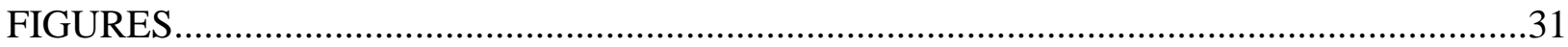

Chapter 3: Size Structure, Age, Growth, and Mortality of Flathead Catfish within the Robert C. Byrd Pool of the Ohio and Kanawha Rivers.........................................................37

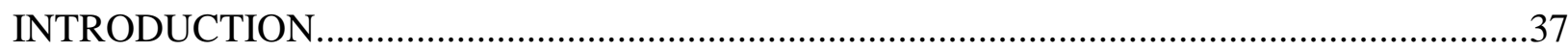

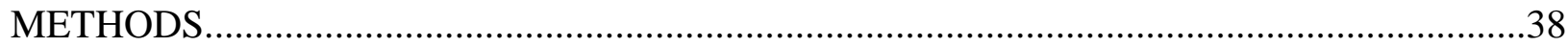

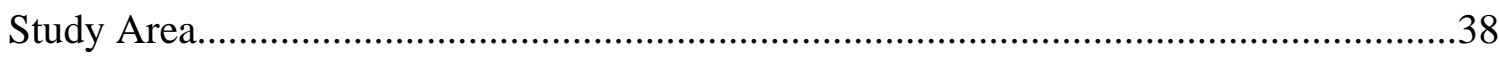

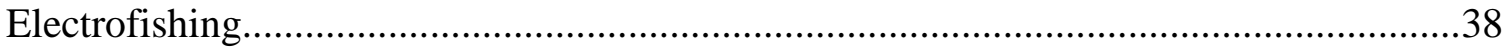

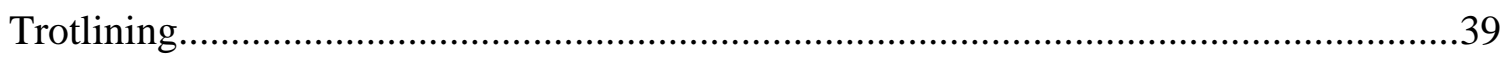

Age and Growth.......................................................................................................

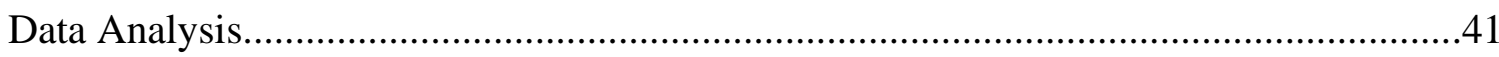

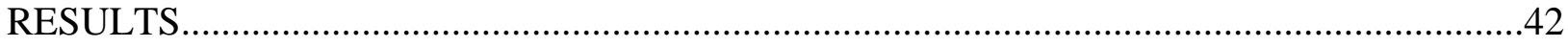

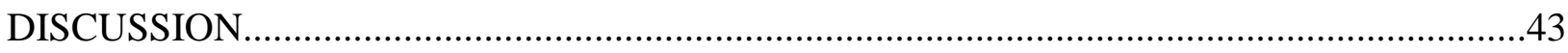

Management Implications..............................................................................................45

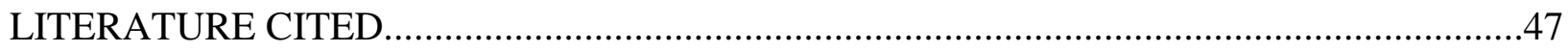

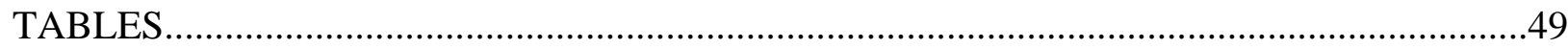

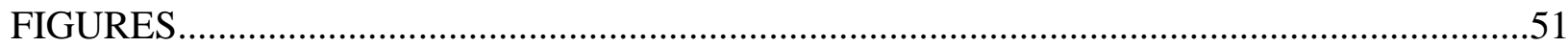

\section{LIST OF TABLES}

\section{Chapter 2}

Table 1. Record of Blue Catfish stocked by the West Virginia Division of Natural Resources within the R. C. Byrd Pool. An asterisk indicates fish held overwinter to attain a larger size

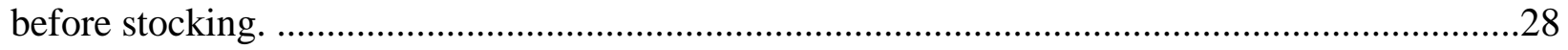

Table 2. CPUE (fish/hour) Blue Catfish collected during low frequency electrofishing surveys on the R. C. Byrd Pool from late May to early June 2017-2020. Fish are separated by Gabelhouse (1984) size classes by TL: Sub-stock $(<$ S), Stock (S), Quality (Q), Preferred (P), Memorable (M) and Trophy (T). Also included are mean values (Mean) along with 95\% Confidence Intervals (2 * Standard Error).

Table 3. CPUE (fish/line night) of Blue Catfish collected during trotline surveys on the R.C. Byrd Pool during Winter 2017-2020. Trotlines contained 20 7/0 circle hooks per line and were baited with live gizzard shad (50-250 mm TL). Fish are separated by Gabelhouse (1984) size 
classes by TL: Sub-stock $(<S)$, Stock $(\mathrm{S})$, Quality (Q), Preferred (P), Memorable $(\mathrm{M})$ and Trophy (T). Also included are mean values (Mean) along with 95\% Confidence Intervals (2* Standard

Error).

\section{Chapter 3}

Table 1. CPUE (fish/hour) Flathead Catfish collected during low frequency electrofishing surveys on the R. C. Byrd Pool from late May to early June 2017-2020. Fish are separated by Gabelhouse (1984) size classes by TL: Sub-stock $(<S)$, Stock (S), Quality (Q), Preferred (P), Memorable (M) and Trophy (T). Also included are mean values (Mean) along with $95 \%$ Confidence Intervals $(2 *$ Standard Error).

Table 2. CPUE (fish/line night) of Flathead Catfish collected during trotline surveys on the R.C. Byrd Pool during November/December 2017-2018 and January 2020-2021 (referred to as 20192020 surveys). Trotlines contained $207 / 0$ circle hooks per line and were baited with live gizzard shad (50-250 mm TL). Fish are separated by Gabelhouse (1984) size classes by TL: Sub-stock $(<$ S), Stock (S), Quality (Q), Preferred (P), Memorable (M) and Trophy (T). Also included are mean values (Mean) along with $95 \%$ Confidence Intervals $(2 *$ Standard Error). .52

\section{LIST OF FIGURES}

\section{Chapter 1}

\section{Chapter 2}

Figure 1. Map of the Robert C. Byrd Pool of the Ohio and Kanawha rivers near the vicinity of Point Pleasant, West Virginia. Survey locations labeled EF and TL were only sampled with electrofishing and trotlining, respectively. Major towns and stocking locations are included as municipalities. The pool boundaries are defined by the Robert C. Byrd, Racine, and Winfield locks and dams.

Figure 2. Left Axis: Age Frequency of Blue Catfish collected from the R.C. Byrd Pool by electrofishing and trotlining. Ages, represented by hatch year, were calculated by subtracting the age estimates for electrofished individuals from 2019 and age estimates for trotlined individuals from 2020, due to aging methodology. Right Axis: Number of Blue Catfish fingerlings stocked by the WVDNR within the R.C. Byrd Pool per year.....

Figure 3. Length at age data by sex and population-wide von Bertalanffy growth curve for Blue Catfish collected from the R.C. Byrd Pool by electrofishing and trotlining. Von Bertalanffy growth parameters and sample size are displayed in bottom right of the figure.....

Figure 4. Mean length at age values from this study (Ohio/Kanawha R. WV) and those from published riverine Blue Catfish growth studies.

Figure 5. Catch curve using all Blue Catfish collected electrofishing $(n=98)$. Unaged fish were assigned ages using an age-length key ( $25 \mathrm{~mm}$ groups). Fish with unassigned ages were assigned 
the age produced from the von Bertalanffy growth function. Estimated annual mortality $=0.085$, $r^{2}=0.164$

Figure 6. Catch curve using age 9+ Blue Catfish collected trotlining $(n=161)$. Unaged fish were assigned ages using an age-length key ( $25 \mathrm{~mm}$ groups). Fish with unassigned ages were assigned the age produced from the von Bertalanffy growth function. Estimated annual mortality $=0.11$, $\mathrm{r}^{2}=0.0741$.

\section{Chapter 3}

Figure 1. Map of the Robert C. Byrd Pool of the Ohio and Kanawha rivers near the vicinity of Point Pleasant, West Virginia. Survey locations labeled EF and TL were only sampled with electrofishing and trotlining, respectively. The pool boundaries are defined by the Robert C. Byrd, Racine, and Winfield locks and dams.

Figure 2. Length at age by sex and population-wide von Bertalanffy growth curve for Flathead Catfish collected from the R.C. Byrd Pool by electrofishing. Von Bertalanffy growth parameters and sample size are displayed in bottom right of the figure.

Figure 3. Mean length at age values from this study (Ohio/Kanawha R. WV) and those from published riverine Flathead Catfish growth studies within their native range.

Figure 4. Catch curve using Flathead Catfish (ages 1-23) collected by electrofishing $(\mathrm{n}=1,554)$. Unaged fish were assigned ages using an age-length key (25 $\mathrm{mm}$ groups). Fish with unassigned ages were assigned the age produced from the von Bertalanffy growth function. Estimated annual mortality $=0.126, \mathrm{r}^{2}=0.63$. 


\section{Chapter 1: Introduction and Literature Review}

\section{Overview and History of the Ohio River}

The Ohio River, a major tributary of the Mississippi River, is located in the eastern United States, and flows 1,579 km from the confluence of the Monongahela and Allegheny Rivers in Pittsburgh, PA to its confluence with the Mississippi River at Cairo, IL. Within the United States, it is the $3^{\text {rd }}$ largest river in average discharge at its mouth $\left(8,000 \mathrm{cubic}^{3} / \mathrm{sec}\right)$, the $8^{\text {th }}$ largest drainage area $\left(525,000 \mathrm{~km}^{2}\right)$, and $9^{\text {th }}$ largest in length $(2108 \mathrm{~km})$ from its source on the Allegheny River (Kammerer 1990). Apart from the Potomac River drainage of the eastern panhandle and a small portion of the James River drainage in the southeastern section, most of the state of West Virginia is drained by the Ohio River through its minor and major tributaries.

Since first European settlement, the Ohio River has experienced a multitude of anthropogenic impacts, resulting in extreme habitat alterations and deterioration of water quality, which significantly altered its aquatic communities. Early explorers characterized the Ohio River as a pristine, slow flowing river, with abundant riparian wetlands and woodlands, clear water, and highly variable water levels (ORSANCO 1962). In the early 1800's, settlers began largescale logging and wetland draining operations to facilitate agriculture, resulting in increased sedimentation, higher turbidity, and increased nutrient loading within the river (Thomas et al. 2005). As populations grew and industrialization took hold, considerable discharges from sewers, coal mines, and steel manufacturing lead to further nutrient loading and decreased dissolved oxygen and $\mathrm{pH}$ levels, especially around developing urban and industrial centers. These effects were particularly strong in the upper reaches of the Ohio, near Pittsburgh, PA and Wheeling, WV (Pearson and Pearson 1989). From 1885-1929, the U.S. Army Corps of Engineers (USACE) constructed a network of 46 wicket dams (since replaced with 18 high-lift 
dams) to maintain a channel of at least $9 \mathrm{ft}$ depth to allow for large boat navigation. These dams marked a considerable change in river morphology and habitat availability, removing riffle regions, slowing current flow, while also increasing dissolved oxygen in the immediate downstream habitats.

By the 1930's, water quality had deteriorated to the point that human intestinal diseases had become common in communities which used the Ohio River for drinking water, leading to the first legislative steps toward remediation. In 1948, the Ohio River Valley Water Sanitation Commission (ORSANCO) was established to monitor water quality and mitigate water pollution within the mainstem (ORSANCO 1983). Sewage treatment facilities were the first established water quality control measures, becoming widespread in the 1950's (Cavanaugh and Mitsch 1989). These measures significantly reduced total dissolved solids (e.g. nitrates, sulfates) as well as the prevalence of low dissolved oxygen levels (Van Hassel et al. 1988). By 1960, both industrial and mining discharges had become regulated, significantly increasing the $\mathrm{pH}$ in affected areas. The Clean Water Act, passed in 1972 added federal protections to the river (Cavanaugh and Mitsch 1989).

The success of water quality regulations is often measured indirectly via fish community assessments (Fausch et al. 1990). On the Ohio River, ORSANCO used rotenone lock surveys from 1957-2005 to monitor fish populations (ORSANCO 1992; ORSANCO unpublished data). Several publications have examined this dataset each asking different questions (Pearson and Krumholz 1984; Pearson and Pearson 1989; Thomas et al. 2005). Overall, the consensus has been fish community health has been improving over time. Pearson and Krumholz (1984) found the largest increases in abundance of all species in the heavily polluted upper Ohio from 1970 to the time of the study. Pearson and Pearson (1989) noted declines in pollution tolerant species as 
total species richness increased. Van Hassel et al. (1988) noted these same trends through an independent electrofishing study. Thomas et al. (2005) showed continued improvement since the 1980's, with significant improvements in fish assemblage metrics since that time. These results are indicative of the long-term successes of the water quality regulations on the Ohio River.

\section{Blue Catfish}

One species which has benefitted from the improved water quality in the Ohio River is the native Blue Catfish (Ictalurus furcatus). The largest catfish species in North America, Blue Catfish favor the deep, swift-flowing, pelagic habitats of large rivers. These difficult to sample habitats have limited the research of this species (Graham 1999). Blue Catfish are opportunistic, generalist feeders, eating a mixture of fish, macroinvertebrates, mussels, vegetation, and detritus (Edds et al. 2002; Eggleton and Schramm, 2004). Blue Catfish are cavity nesters which spawn in spring when waters warm to $21-24^{\circ} \mathrm{C}$ (Cross and Collins 1975) and some have been found to migrate into tributaries during spawning season (Garrett and Rabeni 2011). Extensive movement has been documented in the Upper Mississippi River, which was correlated to season, high discharge, and larger fish size (Tripp et al. 2011).

Records of the Blue Catfish's range within the Ohio River are linked to the river's history of habitat alteration and water quality, however reliable sampling has proven difficult. Trautman (1981) reported their presence in the West Virginia section of the river prior to impoundment, after which river-wide catches decreased, with specimens only collected below the confluence with the Scioto River. By the late 1980's, Pearson and Pearson (1989) found Blue Catfish presence had increased in the lower two thirds of the river, replacing pollution tolerant Ameiurus species in the pools below Greenup Dam. However, Thomas et al. (2005) did not find a significant trend in abundance from 1957-2001. Blue Catfish were not mentioned in Van Hassel 
et al. (1988) which used electrofishing and focused on the upper and middle river, a combination that presumably led to catch rates too low for analysis. In their most recent published pool reports, ORSANCO (2018) collected 12 total Blue Catfish, all within four pools of the lower river. From these reports, it appears that densities of Ohio River Blue Catfish populations are highest in the lower river, and gradually decrease upstream to areas with low numbers or absence. Due to both ecological and recreational interests, the West Virginia Division of Natural Resources (WVDNR) began Blue Catfish fingerling stockings throughout their section of the Ohio River (WVDNR unpublished data).

\section{Flathead Catfish}

Flathead Catfish (Pylodictis olivaris) are another large predator species native to the Mississippi drainage, which thrive in low gradient riverine environments (Jackson 1999). This species is typically most abundant in turbid water but are tolerant of a wide range of turbidities (Lee and Terrell, 1988). Juveniles are nocturnal, feed on benthic macroinvertebrates, and favor riffle habitats (Minckley and Deacon, 1959). Adults are mostly piscivorous (Eggleton and Schramm, 2004) and positively associated with current seams, cover (often woody debris) (Gholson 1975 from Lee and Terrell, 1988), and hard substrate (Minckley and Deacon, 1959). Flathead Catfish are cavity nesters, spawning when water temperatures reach $19-24^{\circ} \mathrm{C}$, typically June to July (Cross and Collins, 1975; Jackson 1999) and prefer temperatures ranging from 21.7$30^{\circ} \mathrm{C}$ (Stauffer 1975 from Lee and Terrell 1988).

Flathead Catfish were previously thought to be sedentary (Jackson 1999), but have more recently been found to migrate seasonally, with more pronounced migrations correlating with the stronger seasonality of the northern latitudes (Piette and Niebur, 2011; Garrett and Rabini, 2011). Movement studies from these areas describe seasonal movement events correlated to Flathead 
Catfish life history, documenting distinct migration periods between spring spawning locations, summer feeding locations, and overwintering holes (Vokoun and Rabeni, 2005; Piette and Niebur, 2011; Garrett and Rabini, 2011; Gelwicks and Simmons, 2011).

It is unclear if Flathead Catfish were fully extirpated from the upper Ohio River during the periods of unregulated water quality, however records indicate Flathead Catfish were common in the river upstream to Marietta, OH after 1900 (Trautman 1981), present in all lockchamber surveys by 1959 (ORSANCO 1963), and abundant throughout the river by 1985 (Reash and Van Hassel 1988). If fully extirpated, it is likely that their rapid recolonization was facilitated by source populations from less polluted tributaries. Currently, Ohio River Flathead Catfish populations offer recreational and, in lowest reaches, commercial fisheries.

\section{Catfish Management}

Recreational management of catfish has increased dramatically over the past twenty years (Michaletz and Dillard 1999; Kwak et al. 2011), correlating with increased recreational interest and desire for trophy fishing opportunities (Arterburn et al. 2002). Successful management requires adequate sampling procedures, driving the ongoing research on sampling efficiency and accuracy. Both Blue and Flathead catfishes occupy large, difficult to sample habitats leading to the utilization of a wide variety of sampling gears, including electrofishing, hoop nets, gill nets, and set lines (Bodine et al. 2013).

Low frequency ( $15 \mathrm{hz}$ ), electrofishing is the most popular (Brown 2009) and efficient sampling gear for Blue and Flathead catfishes (Bodine et al. 2013). Multiple studies sampling populations with known/derived length frequency have found this gear to be biased against Blue Catfish $<200 \mathrm{~mm}$, but otherwise provide a representative sample of the population (Buckmeier 
and Schlechte 2009; Bodine and Shoup 2010). Size selectivity has been less studied in Flathead Catfish, however when compared with other gears in the same system, it is believed to be size selective against fish larger than $600 \mathrm{~mm}$ (Ford et al. 2011; Gelwicks and Steuck 2011; McCain et al. 2011; Bodine et al. 2013). Temporal and environmental factors have been found to effect electrofishing catch rates, with temperatures ranging from $20-28^{\circ} \mathrm{C}$ yielding the highest and most consistent catches for both species (Bodine and Shoup 2010; Travinchek 2011). Additionally, catch rates of Flathead Catfish were negatively impacted by high flows in lotic environments (Travinchek 2011).

Hoop nets, gill nets, and set lines are other gears widely used to sample Blue and Flathead Catfish (Brown 2009). These gears range widely in their specifications (e.g., hoop net gape size, gill net mesh size, hook type and size) making it is difficult to generalize the size selectivity of these gears. This speaks to the need to develop standardized sampling methodologies for catfishes (Vokoun and Rabeni 1999; Bonar and Hubert 2002; Brown 2009; Bodine et al. 2013). In general terms, hoop nets (Ford et al. 2011), gill nets (Evans et al. 2011), and set lines (Gale et al. 1999) are all less efficient than low frequency electrofishing, when deployed in the same study areas.

Research efforts have estimated ages of catfishes, which is vital in determining growth rates, recruitment dynamics, and mortality estimates (Ricker 1975). Counting annuli from lapilli otoliths (Long and Stewart 2010), and pectoral spines are the two prominent methods of aging catfishes (Maceina et al. 2007). Both pectoral spines and otoliths have been found to provide the best measures of Blue Catfish age (Homer et al. 2015), with pectoral spines offering suitable estimates to age 19 (Olive et al. 2011). However, no aging techniques have been validated with known age Blue Catfish (Stewart et al. 2009). Pectoral spines have been validated for Flathead 
Catfish to age 5 (Turner 1980). Age estimates from pectoral spines and otoliths have been found to agree up to age 5 in Flathead Catfish (Nash and Irwin 1999). Flathead Catfish pectoral spines tend to under-estimate age, with otoliths providing significantly more accurate estimates past age 17 (Olive et al. 2011; Steuck and Schnitzler, 2011). Olive et al. (2011) recommended the use of pectoral spines over otoliths in all catfishes, as they are non-lethal and provide age accuracy adequate for analyses.

\section{Thesis Objectives}

The goal of this thesis is to provide baseline population characteristics of both Blue Catfish and Flathead Catfish within the Robert C. Byrd Pool of the Ohio and lower Kanawha Rivers. These findings will guide future management decisions of both species, document the recovery of Blue Catfish, and fill a regional knowledge gap in the population ecology of Flathead Catfish. Specific objectives for both populations include: (1) evaluating size structure through examination of catch rates, (2) estimating growth rates using von Bertalanffy regression, and (3) estimating annual mortality through catch curve analysis. 


\section{Literature Cited}

Arterburn, J. E., D. J. Kirby, and C. R. Berry. 2002. A survey of angler attitudes and biologist opinions regarding trophy catfish and their management. Fisheries 27(5):10-21.

Bodine, K. A., and D. E. Shoup. 2010. Capture efficiency of Blue Catfish electrofishing and the effects of temperature, habitat, and reservoir location on electrofishing-derived length structure indices and relative abundance. North American Journal of Fisheries Management 30:613-621.

Bodine, K. A., D. E. Shoup, J. Olive, Z. L. Ford, R. Krogman, and T. J. Stubbs. 2013. Catfish sampling techniques: where we are now and where we should go. Fisheries 38:529-546.

Bonar, S.A. and W.A. Hubert. 2002. Standard sampling of inland fish: benefits, challenges, and a call for action. Fisheries. 27(3):10-16.

Brown, Z. 2009. Current trends in catfish sampling techniques and information needs. Proceedings of the Annual Conference Southeastern Association of Fish and Wildlife Agencies 61(2007):6-9.

Buckmeier, D. L., and J. W. Schlechte. 2009. Capture efficiency and size selectivity of Channel Catfish and Blue Catfish sampling gears. North American Journal of Fisheries Management 29:404-416.

Cavanaugh, T. M., and W. J. Mitsch. 1989. Water quality trends of the upper Ohio River from 1977 to 1987 . Ohio Journal of Science 89:153-163.

Cross, F. B., and J. T. Collins. 1975. Fishes in Kansas. The University of Kansas Museum of Natural History and State Biological Survey, Lawrence.

Dobbins, D. A., R. L. Cailteux, and J. L. Nordhaus. 1999. Flathead catfish abundance and movement in the Apalachicola River, Florida. Pages 199-202 in E. R. Irwin, W. A. Hubert, C. F. Rabeni, H. L. Schramm, Jr., and T. Coon, editors. Catfish 2000: Proceedings of the International Ictalurid Symposium. American Fisheries Society, Symposium 24, Bethesda, Maryland.

Edds, D. R., W. J. Matthews, and F. P. Gelwick. 2002. Resource use by large catfishes in a reservoir: Is there evidence for interactive segregation and innate differences? Journal of Fish Biology 60:739-750.

Eggleton, M. A., and H. L. Schramm. 2004. Feeding ecology and energetic relationships with habitat of blue catfish, Ictalurus furcatus, and flathead catfish, Pylodictis olivaris, in the lower Mississippi River, USA. Environmental Biology of Fishes 70:107-121.

Evans, N. T., D. E. Shoup, and K. E. Kuklinski. 2011. Comparison of electrofishing and experimental gill nets for sampling size structure and relative abundance of Blue Catfish in reservoirs. Pages 599-606 in P. H. Michaletz and V. H. Travnichek, editors. Conservation, Ecology, and Management of Catfish: the Second International Symposium. American Fisheries Society, Symposium 77, Bethesda, Maryland. 
Fausch, K.D., Lyons, J., Karr, J.R., and Angermeier, P.L. 1990. Fish communities as indicators of environmental degradation. In Biological Indicators of Stress in Fish. American Fisheries Society Symposium. Edited by S.M. Adams. American Fisheries Society, Bethesda, Maryland.

Ford, Z. L., K. P. Sullivan, I. W. Vining, T. G. Kulowiec, G. D. Pitchford, H. R. Dames, R. J. Dent, and E. Colvin. 2011. Sampling statistics and size distributions for Flathead Catfish populations in four Missouri Rivers. Pages 95-104 in P. H. Michaletz and V. H. Travnichek, editors. Conservation, Ecology, and Management of Catfish: the Second International Symposium. American Fisheries Society, Symposium 77, Bethesda, Maryland.

Gale, C. M., K. Graham, K. DeiSanti, and J. S. Stanovick. 1999. Sampling strategies for Blue Catfish and Channel Catfish in the Harry S. Truman Dam tailwater, Missouri. Pages 301307 in E. R. Irwin, W. A. Hubert, C. F. Rabeni, H. L. Schramm, Jr., and T. Coon, editors. Catfish 2000: Proceedings of the International Ictalurid Symposium. American Fisheries Society, Symposium 24, Bethesda, Maryland.

Garrett, D. L., and C. F. Rabeni. 2011. Intra-annual movement and migration of flathead catfish and blue catfish in the lower Missouri River and tributaries. Pages 495-509 in P. H. Michaletz and V. H. Travnichek, editors. Conservation, Ecology, and Management of Catfish: the Second International Symposium. American Fisheries Society, Symposium 77, Bethesda, Maryland.

Gelwicks, G. T., and G. A. Simmons. 2011. Range and seasonal movements of flathead catfish in the Iowa River, Iowa. Pages 443-453 in P. H. Michaletz and V. H. Travnichek, editors. Conservation, Ecology, and Management of Catfish: the Second International Symposium. American Fisheries Society, Symposium 77, Bethesda, Maryland.

Gelwicks, G. T. and M. J. Steuck. 2011. Evaluation of the status, distribution and habitats of flathead catfish in Iowa's rivers. Iowa Department of Natural Resources. Federal Aid in Sport Fish Restoration, Project F-160-R, Completion Report, Des Moines.

Graham, K. 1999. A review of the biology and management of blue catfish. Pages 37-50 in E. R. Irwin, W. A. Hubert, C. F. Rabeni, H. L. Schramm, Jr., and T. Coon, editors. Catfish 2000: Proceedings of the International Ictalurid Symposium. American Fisheries Society, Symposium 24, Bethesda, Maryland.

Gholson, K. W. 1975. Life history of the flathead catfish (Pylodictis olivaris). Texas Parks and Wildlife, Federal Aid Project F-31-R-1, Annual Report, Austin.

Homer, M. D., J. T. Peterson, and C. A. Jennings. 2015. Evaluation of three aging techniques and back-calculated growth for introduced blue catfish from Lake Oconee, Georgia. Southeastern Naturalist 14:740-756.

Jackson, D. C. 1999. Flathead catfish: biology, fisheries, and management. Pages 23-35 in E. R. Irwin, W. A. Hubert, C. F. Rabeni, H. L. Schramm, Jr., and T. Coon, editors. Catfish 2000: Proceedings of the International Ictalurid Symposium. American Fisheries Society, Symposium 24, Bethesda, Maryland. 
Kammerer, J.C. 1990. Largest rivers in the United States. United States Geological Survey Water Resources Division, Reston, Virginia.

Kwak, T. J., M. T. Porath, P. H. Michaletz, \& V. H. Travnichek. 2011. Catfish science: status and trends in the 21st century. Pages 755-780 in P. H. Michaletz and V. H. Travnichek, editors. Conservation, Ecology, and Management of Catfish: the Second International Symposium. American Fisheries Society, Symposium 77, Bethesda, Maryland.

Lee, L. A., and J. W. Terrell. 1987. Habitat suitability index models: flathead catfish. Biological Report 82 (10.152). U.S. Department of the Interior, Fish and Wildlife Service, Research and Development, Washington, D.C.

Long, J. M., and D. R. Stewart. 2010. Verification of otolith identity used by fisheries scientists for aging channel catfish. Transactions of the American Fisheries Society 139:17751779.

Maceina, M. J., J. Boxrucker, D. L. Buckmeier, R. S. Gangl, D. O. Lucchesi, D. A. Isermann, J. R. Jackson, and P. J. Martinez. 2007. Current status and review of freshwater fish aging procedures used by state and provincial fisheries agencies with recommendations for future directions. Fisheries 32:329-340.

Michaletz, P. H., and J. G. Dillard. 1999. A survey of catfish management in the United States and Canada. Fisheries 24(8):6-11.

Minckley, W. L., and J. E. Deacon. 1959. Biology of the flathead catfish in Kansas. Transactions of the American Fisheries Society 88:344-355.

McCain, K. N. S., J. W. Ridings, Q. Phelps, and R. A. Hrabik. 2011. Population trends of Flathead Catfish, Channel Catfish, and Blue Catfish in impounded and unimpounded reaches of the upper Mississippi River (1993-2007). Pages 141-154 in P. H. Michaletz and V. H. Travnichek, editors. Conservation, Ecology, and Management of Catfish: the Second International Symposium. American Fisheries Society, Symposium 77, Bethesda, Maryland.

ORSANCO (Ohio River Valley Water Sanitation Commission). 1962. Aquatic-life resources of the Ohio River. ORSANCO, Cincinnati, Ohio.

ORSANCO (Ohio River Valley Water Sanitation Commission). 1992. Assessment of ORSANCO fish population data using the modified index of well being (MIWB). ORSANCO, Cincinnati, Ohio.

Olive, J., H. L. Schramm, Jr., P. D. Gerard and E. R. Irwin. 2011. An evaluation of agreement between pectoral spines and otoliths for estimating ages of catfishes. Pages 679-688 in P. H. Michaletz and V. H. Travnichek, editors. Conservation, Ecology, and Management of Catfish: the Second International Symposium. American Fisheries Society, Symposium 77, Bethesda, Maryland.

Pearson, W. D., and L. A. Krumholz. 1984. Distribution and status of Ohio River fishes. Oak Ridge National Laboratory, ORNL/SUB/79-7831/1, Oak Ridge, Tennessee. 
Pearson, W. D., and B. J. Pearson. 1989. Fishes of the Ohio River. The Ohio Journal of Science 89(5):181-187.

Piette, R. R., and A. D. Niebur. 2011. Movement of adult male flathead catfish in the upper Fox River and Wolf River systems determined by radiotelemetry. Pages 455-471 in P. H. Michaletz and V. H. Travnichek, editors. Conservation, Ecology, and Management of Catfish: the Second International Symposium. American Fisheries Society, Symposium 77, Bethesda, Maryland.

Reash, R. J., and J. H. Van Hassel. 1988. Distribution of upper and middle Ohio River fishes, 1973-85: II. Influence of zoogeographic and physicochemical tolerance factors. Journal of Freshwater Ecology 4:459-476.

Ricker, W. E. 1975. Computation and interpretation of biological statistics of fish populations. Fisheries Research Board of Canada Bulletin 191.

Stauffer, K. W., and B. D. Koenen. 1999. Comparison of methods for sampling Flathead Catfish in the Minnesota River. Pages 329-333 in E. R. Irwin, W. A. Hubert, C. F. Rabeni, H. L. Schramm, Jr., and T. Coon, editors. Catfish 2000: Proceedings of the International Ictalurid Symposium. American Fisheries Society, Symposium 24, Bethesda, Maryland.

Steuck, M. J. and C. C. Schnitzler. 2011. Age and growth of flathead catfish from pools 12 and 13 of the upper Mississippi River. Pages 699-712 in P. H. Michaletz and V. H. Travnichek, editors. Conservation, Ecology, and Management of Catfish: the Second International Symposium. American Fisheries Society, Symposium 77, Bethesda, Maryland.

Stewart, D. R., G. W. Benz, and G. D. Scholten. 2009. Weight-length relationships and growth data for blue catfish from four Tennessee waterbodies. Proceedings of the Annual Conference Southeastern Association of Fish and Wildlife Agencies 63:140-146.

Thomas, J. A., E. B. Emery and F. H. McCormick. 2005. Detection of temporal trends in Ohio River fish assemblages based on lockchamber surveys (1957-2001). Pages 431-450 in In J. N. Rinne, H. R. Hughes and R. Calamusso, editors. Historical changes in large river fish assemblages of the Americas. American Fisheries Society, Bethesda, Maryland.

Trautman, M. B. 1981. The Fishes of Ohio, Revised Edition. Ohio State University Press, Columbus, Ohio.

Travnichek, V. H. 2011. Monthly variation and influences of habitat and river stage on electrofishing catch rates and population indices of Flathead Catfish from the lower Missouri River. Pages 621-635 in P. H. Michaletz and V. H. Travnichek, editors. Conservation, Ecology, and Management of Catfish: the Second International Symposium. American Fisheries Society, Symposium 77, Bethesda, Maryland.

Tripp, S. J., M. J. Hill, H. A. Calkins, R. C. Brooks, D. P. Herzog, D. E. Ostendorf, R. A. Hrabik, and J. E. Garvey. 2011. Blue catfish movement in the upper Mississippi River. Pages 511-519 in P. H. Michaletz and V. H. Travnichek, editors. Conservation, Ecology, and Management of Catfish: the Second International Symposium. American Fisheries Society, Symposium 77, Bethesda, Maryland. 
Turner, P. R. 1980. Procedures for age determination and growth rate calculations for flathead catfish. Proceedings of the Annual Conference Southeastern Association of Fish and Wildlife Agencies 34:253-262.

Van Hassel, J. H., R. J. Reash, H. W. Brown, J. L. Thomas, and R. C. Matthews, Jr. 1988. Distribution of upper and middle Ohio River fishes, 1973-85: I. Associations with water quality and ecological variables. Journal of Freshwater Ecology 4:441-458.

Vokoun, J. C., and C. F. Rabeni. 1999. Catfish sampling in rivers and streams: a review of strategies, gears, and methods. Pages 621-635 in E. R. Irwin, W. A. Huber, C. F. Rabeni, H. L. Schramm, Jr., and T. Coon, editors. Catfish 2000: Proceedings of the International Ictalurid Symposium. American Fisheries Society, Symposium 24, Bethesda, Maryland.

Vokoun, J. C., and C. F. Rabeni. 2005. Variation in an annual movement cycle of flathead catfish within and between two Missouri watersheds. North American Journal of Fisheries Management 25:563-572. 


\section{Chapter 2: Evaluation of a Recovering Blue Catfish Population within the middle Ohio and lower Kanawha Rivers}

\section{Introduction}

The extirpation of native populations is a common concern for natural resource managers, particularly when the loss of a population has implications across several ecological levels (Fraser et al. 2015). For example, population extirpation of an apex predator will likely influence community and ecosystem function (Nifong and Silliman 2012). From a management perspective, reestablishment of an extirpated population may be possible through stocking and restocking of individuals (Stier et al. 2016). Evaluation of successful reestablishment of an extirpated population, however, often involves an initial focus on characteristics of the recovering population. Thus, during the reestablishment of a population, natural resource managers may choose to evaluate population characteristics, such as age and growth, mortality, and natural reproduction.

For freshwater fishes, populations of apex predators are often managed as fisheries, where they are recreationally and/or commercially valued and exploited (Winemiller et al. 2016). Thus, in the aftermath of population extirpation, successful population reestablishment may provide economic value as a restored fishery, as well as value toward ecosystem function. The reestablishment of a fish population, particularly if the species is an apex predator, can be challenging, and stocking and restocking of individuals over many years may be required to restore the population (Smith et al. 2020). Size limits or creel limits may be useful as management strategies to reduce harvest mortality (Noble and Jones 1993). Alternatively, success in restoring the population and the fishery may be limited if the environmental conditions or reasons for the population extirpation remain unchanged (Cochran-Biederman et al. 
2015). Managers gauge success by examining vital rates of the population: survival, growth, and recruitment.

The Blue Catfish (Ictalurus furcatus), a large-bodied apex predator, was considered extirpated from the Ohio and Kanawha rivers in West Virginia, USA. Prior to lock and dams, Blue Catfish were present in West Virginia's section of the Ohio River, but population densities at that time are unknown (Trautman 1981). Population extirpation was likely due to water pollution, and habitat alteration from lock and dams, as well as urban, industrial, and agricultural areas rapidly emerging in the $19^{\text {th }}$ century. Water quality legislation in the mid- $20^{\text {th }}$ century has mitigated some alterations, most notably in the acutely affected upper $300 \mathrm{~km}$ of the Ohio River (Cavanaugh and Mitsch 1989) and Kanawha River below Charleston, WV (Messenger 1997). As a result, the upper Ohio River has seen increasing abundance of pollution intolerant forage and sportfishes (Van Hassel et al. 1988). By the late 1980's, Blue Catfish presence had increased, replacing pollution tolerant Ameiurus species in the lower two thirds of the river, below Greenup Dam (Pearson and Pearson 1989). However, populations had yet to be established in West Virginia's waters of the Ohio River, where it will likely provide a popular recreational fishery (Arterburn et al. 2002).

From 2004-2015, a repatriation program was conducted by the West Virginia Division of Natural Resources (WVDNR) to reestablish Blue Catfish into the Robert C. Byrd Pool of the Ohio and Kanawha rivers. Blue Catfish fingerlings were stocked throughout the pool at public access sites, generally in the fall months (Table 1). Most fingerlings originated from the lower Ohio River, provided by the Kentucky Department of Fish and Wildlife Resources, and were supplemented by those from Osage Catfisheries Inc., AR. Numbers stocked varied by year and no fish were stocked in 2005 or 2008. Current West Virginia regulations, which allow for the 
daily harvest of two Blue Catfish over 24 inches $(609.6 \mathrm{~mm})$, are designed to allow fish to reach reproductive maturity before exposure to fishing mortality.

Although our future goal is to evaluate ecosystem-level implications of Blue Catfish in the Robert C. Byrd Pool of the Ohio and Kanawha Rivers, our initial focus herein was to examine and document characteristics of the recovering population. Specifically, our objectives were to estimate size and age structure, growth, and mortality of a recovering Blue Catfish population, hence providing baseline data for management decisions and future community- and ecosystem-level studies.

\section{Methods:}

\section{Study Area}

The Robert C. Byrd Pool consists of the $51 \mathrm{~km}$ section below Winfield dam on the Kanawha River, and the $61 \mathrm{~km}$ stretch between the Racine and Robert C. Byrd dams on the Ohio River (Figure 1). Both are large navigable rivers, with heavy barge traffic. The pool is dredged to maintain a minimum depth of $2.75 \mathrm{~m}$ but averages $8 \mathrm{~m}$ deep. The rivers are low gradient, with a bottom composition of mainly fines and sand (ORSANCO 2013). Typical water conditions during surveys ranged from high turbidity to $0.5 \mathrm{~m}$ Secchi depth.

\section{Electrofishing}

We modeled our annual electrofishing survey design off the recommendations by Bodine et al. (2013). We used $15 \mathrm{hz}$, low frequency electrofishing (Smith Root GPP 5.0, 200V) which is non size selective for Blue Catfish between 200 and $1000 \mathrm{~mm}$ in reservoirs (Buckmeier and Schlechte 2009; Bodine and Shoup 2010). We surveyed in late May to early June 2017-2020 when water temperatures were between $18^{\circ} \mathrm{C}$ and $28^{\circ} \mathrm{C}$, a temperature range associated with 
high, consistent catch rates for low frequency electrofishing (Bodine and Shoup 2010). We selected 10 sites distributed throughout the study area using a combination of angler input and targeted habitat: outside bends, rip-rap banks, steep drop offs, and tailwaters. We surveyed two sites per day from late morning into the afternoon. We ran the electrofishing boat approximately $10 \mathrm{~m}$ from the bank downstream in four 15-minute transects per site and used a single chase boat to facilitate fish capture.

\section{Trotlining}

Due to low electrofishing catch rates during a 2016 pilot study, we decided to include trotline surveys for increased sample size. Trotlines are rarely used in the literature but have been shown to select for the largest individuals in a population, potentially revealing the trophy potential within this system (Gale et al. 1999). We designed the survey using the same 10 sites as the electrofishing survey, however we moved tailwater sites downstream (approximately 1-20 $\mathrm{km}$ ) of dams to the next targeted habitat, owing to safety concerns associated with swift currents.

The pilot study also showed temporal species selectivity while trotlining, presumably due to water temperature and metabolic effects. Initial trotline sets in October led to high Flathead Catfish (Pylodictis olivaris) catches. We theorized that due to the finite number of hooks, Flathead Catfish catches would negatively affect Blue Catfish catch rates. We trialed sets in November and December and observed more even catches between species. With this knowledge, we surveyed from November-December in 2017 and 2018. These dates moved back to January 2020-2021 (referred to as the 2019-2020 surveys) due to scheduling conflicts but effects of this shift timing are seen in catch data. 
Each trotline set consisted of a set of 3 weights and 2 floats, equipped with 20 7/0 Eagle Claw Lazer Sharp Circle Sea hooks. We baited with live Gizzard Shad from 50-300 mm TL, caught electrofishing from an embayment within the study area the day of sampling. We chose to use live shad as they constitute the largest biomass of fish in the pool and are a natural forage species for Blue Catfish. We set 5 lines off the bank at each site, ensuring the first hook was set at a depth greater than $3 \mathrm{~m}$. We fished the lines overnight.

\section{Age and Growth}

We collected all Blue Catfish for aging during our previously described 2019 electrofishing and January 2020 trotlining surveys. We utilized lapilli otoliths for aging (Long and Stewart 2010), which provide accurate ages for ictalurids (Nash and Irwin 1999; Buckmeier et al. 2002; Jolley and Irwin 2011). Both Olive et al. (2011) and Homer et al. (2015) found pectoral spines and otoliths to be valid measures of Blue Catfish age. Neither of these aging methods have been validated with known age individuals (Stewart et al. 2009).

We extracted, mounted, and aged otoliths using methods from Buckmeier et al. (2002) with several modifications. We chose not to burn otoliths on a hot plate prior to mounting to prevent unreadability due to over toasting. We also used water instead of mineral oil while viewing/photographing to enhance annuli clarity. We used a dissecting microscope with camera to photograph each prepared otolith. We incrementally sanded to the core, taking multiple photographs of each otolith as we progressed. This ensured we captured the clearest images of the annuli. Two independent readers aged each otolith from the images, reconciling disagreements through concert readings. Spring electrofishing otoliths were aged by counting the annuli whereas winter trotlining otoliths were aged by counting the annuli plus the edge, as we presumed that the outer annulus was being laid down during the time of collection. 


\section{Data Analysis}

All Blue Catfish collected during our surveys were counted and total length measured to the nearest millimeter. We calculated CPUE as number of fish per hour (fish / hr) and number of fish per line night (fish / line night) for electrofishing and trotlining, respectively. We estimated size structure by comparing non-size selective catch data (electrofishing CPUE) through size classes (in millimeters) defined by Gabelhouse (1984): Sub-stock <300, Stock 300-510, Quality 510-760, Preferred 760-890, Memorable 890-1140, and Trophy >1140. We calculated mean annual CPUE values as well as $95 \%$ Confidence intervals by $2 *$ standard error. We compared our catch data to a hypothesized population experiencing constant recruitment and mortality

With our aged individuals, we calculated hatch year, subtracting the age estimate for electrofishing from 2019 and age estimate for trotlining from 2020, due to aging methodology. We compared hatch year to the stocking records to infer the origin of each fish. We performed a simple linear regression in Microsoft Excel between fingerlings stocked and age frequency of our aged individuals to determine the relationship between stocking rates and recruitment. Sacrificing individuals for age analysis allowed us to sex individuals through visual inspection of the gonads. We plotted length at age by sex to visually determine differential growth between sexes.

We modeled growth using ages from individuals obtained through both gears. We used Fisheries Analysis and Modeling Simulator (FAMS) (Slipke and Maceina 2014) to solve for the von Bertalanffy (1938) parameters in the equation:

$$
L_{t}=L_{\infty}\left(1-\mathrm{e}^{-k(t-t o)}\right)
$$


where: $L_{\infty}=$ maximum theoretical length (length infinity) that can be obtained; $k=$ growth coefficient; $t=$ time or age in years; $t o=$ is the time in years when length would theoretically be equal to zero and; e = exponent for natural logarithms. Growth regressions by sex failed to parameterize and were omitted.

We used FAMS, to calculate mean length at age values, which we plotted with published riverine Blue Catfish population data for comparison (Conder and Hoffarth 1965; Greenlee and Lim 2011; Kelley 1969; Stewart et al. 2009). We assigned ages to all fish collected in FAMS using weighted average probability methodology in the age length key ( $25 \mathrm{~mm}$ size bins). Fish not receiving ages were assigned the age produced from the von Bertalanffy growth function. Due to sample size limitations, we constructed catch curves (Ricker 1974) in FAMS for both electrofishing and trotlining, using the weighted regression function to estimate mortality (Maceina 1997). We included all ages for electrofishing and ages 9+ for trotlines to account for the size selective bias. We compared mortality estimates between gears, considering how catch curve assumptions affect these estimates.

\section{Results}

We electrofished and captured a total of 101 Blue Catfish. Electrofishing CPUE values were low and variable across survey years, with total CPUE values ranging from 1.83 in 2018 to 3.26 in 2020 (Table 2). The 95\% confidence intervals of CPUE estimates were wide for all size classes, and included zero in sub-stock, preferred, memorable, and trophy sizes (Table 2). Size structure deviated from that expected of a theoretical population with constant recruitment and mortality in that sub-stock and preferred size classes had lower catch rates than their next largest size class. 
We collected 242 Blue Catfish during our trotline surveys. Catch rates from trotlines varied less than those from electrofishing by size class and year (Table 3). Confidence intervals did not include zero for quality size and larger size classes. We collected only one stock size and zero sub-stock fish from trotlines, likely due to gape limitation associated with whole Gizzard Shad and 7/0 circle hooks. We observed catches of preferred sized fish consistently lower than those of memorable sized fish.

We successfully aged 88 of the 96 Blue Catfish collected for aging (31 from electrofishing). We observed a minimum age of 2 and maximum age of 21. We back dated all individuals to hatch year, subtracting the age estimates from the year 2019 for electrofishing and 2020 for trotlines. We compared the frequency of these ages to the fingerling stocking rates over the same years (Figure 2). Aged individuals post- and pre-dated the stocking window, offering evidence of natural reproduction and persistence prior to stocking. Trophy sized Blue Catfish aged back to the first fingerling stockings in 2004. Nine- and ten-year-old fish made up a significant portion of the sample $(n=17,26$; respectively). There was only a weak linear correlation between fingerlings stocked and age frequency of all aged individuals $\left(\mathrm{r}^{2}=0.29\right)$. We found little evidence for sexually dimorphic growth within the population (Figure 3). The von Bertalanffy regression had a good fit $\left(\mathrm{r}^{2}=0.937\right)$ and a high $L_{\infty}(1413 \mathrm{~mm})$ (Figure 3$)$. We found the R.C. Byrd population's growth rates to be approximately average when compared to data published for other populations (Figure 4). Our catch curves for electrofishing and trotlining indicated low annual mortality in the population (0.085 and 0.11), respectively (Figures 5 and 6). However, the quality of fit was poor for both gears, $r^{2}=0.164$ and 0.07 . Variation in the age frequency data contributed to the poor regression correlation. 


\section{Discussion:}

Given that few studies have been conducted on the repatriation and recovery of apex predators in riverine systems, this study provided an opportunity to study the dynamics of these efforts. Fifteen years into the recovery, our catch rates indicate a small population of Blue Catfish relative to the other large bodied ictalurids, Channel Catfish (Ictalurus punctatus) and Flathead Catfish, suggesting a long temporal scale for this repatriation process. This is potentially driven by our observed variable recruitment compounded by competition with these species, which occupy similar niches. We observed low mortality in recruited individuals and average growth which suggest Blue Catfish will establish themselves in greater numbers over time. However, there is much uncertainty due to the complexity of the ecosystem. These data provide a case-study of these efforts in a large river environment, along with broad-scale insights into the succession of these initiatives.

\section{Variable Recruitment}

Our evidence of annual recruitment variability in our length frequency data, age frequency data, and catch curve results could have several explanations. A gear or sample size influence is possible, but we collected less preferred than memorable size fish in both electrofishing and trotlining, deviating from a size distribution resulting from uniform recruitment. Additionally, we aged few fish which date back to 2005-2008 and 2012-2015. These year class gaps are poorly explained by fingerling stocking rates, but may be related to environmental conditions at the time of stocking. Stocking success could also be influenced by habitats available to recently stocked fingerlings (i.e., those close in proximity to stocking location). Young-of-year Blue Catfish have been related to areas with low water velocity, such as side channels and around islands and away from main channel habitats (Seibert et al. 2017). 
Additionally, during our electrofishing surveys we collected several sub-stock individuals in the calm water behind lock chambers.

\section{Natural Reproduction}

Out of the 88 aged Blue Catfish, 12 Blue Catfish aged back to 2016 and 3 back to 2017. With the WVDNR stocking suspended in 2015, these fish offer evidence for natural reproduction in the system. We also collected sub-stock Blue Catfish in every electrofishing survey, including the 2020 survey, where 19 of our total 33 Blue Catfish were sub-stock size. Further, our von Bertalanffy regression indicates the average Blue Catfish recruits to stock size in 2.5 years, meaning the sub-stock fish collected in the 2017 (or 2018, conservatively) electrofishing surveys onward were likely the result of natural reproduction. These may even be under-represented in the catch data, due to a gear bias against sub-200 mm fish (Bodine and Shoup 2010). These findings affirm those of Owens (2019) who found young-of-year Blue Catfish in benthic trawls of the R.C. Byrd Pool.

\section{Growth}

The von Bertalanffy regression reports a high $L_{\infty}(1413 \mathrm{~mm})$ combined with consistent catches of trophy sized individuals suggests the production of very large fish in the future. It is also possible this $L_{\infty}$ is overestimated. Slow growth in younger individuals (possible due to density dependent growth) can give the impression of sustained fast growth at higher sizes, artificially inflating $L_{\infty}$ when growth rates are decreasing in the system over time.

Growth rates to comparable studies were unexpected due to this population's recent reintroduction and its low densities, which are commonly linked with fast growth in introduced fish populations. Our growth rates are most comparable to those of the James River, VA 
(Greenlee and Lim 2011) and the Mississippi River, TN and MO (Stewart et al. 2009) both of which are very different systems. Densities are higher in the tidal James River, electrofishing CPUE values from Greenlee and Lim's (2011) study range from 754 to 4,449 fish/hr, compared to our mean CPUE of 2.57. The stretch of Mississippi River studied in Stewart et al. (2009) contains a commercially fished population. Blue Catfish have historically persisted in this reach, which is much larger and therefore offers more pelagic habitat.

\section{Mortality}

Our catch curves for both gears had poor fits but indicated around 10\% annual mortality. This value is higher than the 5.5\% found in the lower Wabash River, IN and IL (Donabauer 2009), but lower than both the $26.5 \%$ reported for the James River, VA (Greenlee and Lim 2011). We found our annual mortality estimates were also lower than those found in southern reservoir populations: $26 \%$ OK state average (seven reservoirs, Boxrucker and Kuklinski 2008) and 19.5\% Lake Wilson, AL (Holley et al. 2009). However, our low estimates are likely being brought down by 0 's in the age classes (sample size limitations), resulting in a flatter curve and lower reported mortality.

We suspect the stocked population experiences high mortality during a critical period following stocking due to a low correlation between stocking rate and hatch year age frequency, but experiences low mortality at a larger size, likely after their first winter. We assume the fishing component of mortality is low as well. We suspect most anglers in the R.C. Byrd Pool practice catch and release, due to desires to support a trophy fishery as well as consumption advisories. Hooking mortality is likely low, as maximum values have been found to be $\sim 25 \%$ at temperatures $>20^{\circ} \mathrm{C}$ and decrease rapidly with water temperature (Schmidtt and Shoup 2013). 


\section{Management Implications}

As the Blue Catfish population recovers within the Robert C. Byrd pool of the Ohio and lower Kanawha rivers, we expect the top-down influence of this apex predator to have beneficial impacts on the riverine ecosystem. Abundances of apex predators are expected to be lower than those of other species within the fish community, thus our data supporting a slow recovery of the Blue Catfish population is not unexpected. With evidence of natural reproduction, managers may consider the discontinuation of stocking as a conservative management approach. However, the extent of which natural recruitment varies from that of the fingerling stockings is unknown. High natural recruitment would allow natural reproduction to increase the population to an abundance mediated by the ecosystem. Lower natural recruitment would slow this process and may result in the higher growth rates and continued production of trophy fish due to density dependent effects. There is also a possibility that natural recruitment alone will not sustain the population, leading to eventual extirpation. To quantify the success of natural reproduction, we recommend reevaluating this population at a time where naturally recruited year classes make up a more significant portion of the population ( 10 years) and comparing catch rates to those from this study. 


\section{Literature Cited:}

Arterburn, J. E., D. J. Kirby, and C. R. Berry. 2002. A survey of angler attitudes and biologist opinions regarding trophy catfish and their management. Fisheries 27(5):10-21.

Bodine, K. A., and D. E. Shoup. 2010. Capture efficiency of Blue Catfish electrofishing and the effects of temperature, habitat, and reservoir location on electrofishing-derived length structure indices and relative abundance. North American Journal of Fisheries Management 30:613-621.

Bodine, K. A., D. E. Shoup, J. Olive, Z. L. Ford, R. Krogman, and T. J. Stubbs. 2013. Catfish sampling techniques: where we are now and where we should go. Fisheries 38:529-546.

Boxrucker, J., and K. Kuklinski. 2008. Abundance, growth, and mortality of selected Oklahoma blue catfish populations: implications for management of trophy fisheries. Proceedings of the Annual Conference Southeastern Association of Fish and Wildlife Agencies 60:152156.

Buckmeier, D. L., E. R. Irwin, R. K. Betsill, and J. A. Prentice. 2002. Validity of otoliths and pectoral spines for estimating ages of channel catfish. North American Journal of Fisheries Management 22:934-942.

Buckmeier, D. L., and J. W. Schlechte. 2009. Capture efficiency and size selectivity of Channel Catfish and Blue Catfish sampling gears. North American Journal of Fisheries Management 29:404-416.

Cavanaugh, T. M., and W. J. Mitsch. 1989. Water quality trends of the upper Ohio River from 1977 to 1987 . Ohio Journal of Science 89:153-163.

Cochran-Biederman, J. L., K. E. Wyman, W. E. French, and G. L. Loppnow. 2015. Identifying correlates of success and failure of native freshwater fish reintroductions. Conservation Biology 29:175-186.

Conder, J. R., and R. Hoffarth. 1965. Growth of channel catfish, Ictalurus punctatus, and blue catfish, Ictalurus furcatus, in the Kentucky Lake portion of the Tennessee River in Tennessee. Proceedings of the Annual Conference Southeastern Association of Game and Fish Commissioners 16(1962):348-354.

Donabauer, S. B. 2009. Population dynamics of flathead, channel, and blue catfish in the Wabash River. Indiana Department of Natural Resources, Work Plan 204771 Final Report, Indianapolis.

Gabelhouse, D. W., Jr. 1984. A length-categorization system to assess fish stocks. North American Journal of Fisheries Management 4:273-28.

Gale, C. M., K. Graham, K. DeiSanti, and J. S. Stanovick. 1999. Sampling strategies for Blue Catfish and Channel Catfish in the Harry S. Truman Dam tailwater, Missouri. Pages 301307 in E. R. Irwin, W. A. Hubert, C. F. Rabeni, H. L. Schramm, Jr., and T. Coon, editors. Catfish 2000: Proceedings of the International Ictalurid Symposium. American Fisheries Society, Symposium 24, Bethesda, Maryland. 
Graham, K. 1999. A review of the biology and management of blue catfish. Pages 37-50 in E. R. Irwin, W. A. Hubert, C. F. Rabeni, H. L. Schramm, Jr., and T. Coon, editors. Catfish 2000: Proceedings of the International Ictalurid Symposium. American Fisheries Society, Symposium 24, Bethesda, Maryland.

Greenlee, R. S., and C. N. Lim. 2011. Searching for equilibrium: population parameters and variable recruitment in introduced Blue Catfish populations in four Virginia tidal river systems. Pages 349-367 in P. H. Michaletz and V. H. Travnichek, editors. Conservation, Ecology, and Management of Catfish: the Second International Symposium. American Fisheries Society, Symposium 77, Bethesda, Maryland.

Holley, M. P., M. D. Marshall, and M. J. Maceina. 2009. Fishery and population characteristics of blue catfish and channel catfish and potential impacts of minimum length limits on the fishery in Lake Wilson, Alabama. North American Journal of Fisheries Management 29:1183-1194.

Homer, M. D., J. T. Peterson, and C. A. Jennings. 2015. Evaluation of three aging techniques and back-calculated growth for introduced blue catfish from Lake Oconee, Georgia. Southeastern Naturalist 14:740-756.

Jolley, J. C., and E. R. Irwin. 2011. Catfish population characteristics in tailwater reservoir habitats of the Coosa River, Alabama. Pages 155-166 in P. H. Michaletz and V. H. Travnichek, editors. Conservation, Ecology, and Management of Catfish: the Second International Symposium. American Fisheries Society, Symposium 77, Bethesda, Maryland.

Kelley, J. R. 1969. Growth of blue catfish Ictalurus furcatus (LeSueur) in the Tombigbee River of Alabama. Proceedings of the Annual Conference Southeastern Association of Game and Fish Commissioners 23:248-255.

Long, J. M., and D. R. Stewart. 2010. Verification of otolith identity used by fisheries scientists for aging channel catfish. Transactions of the American Fisheries Society 139:17751779.

Maceina M. J. 1997. Simple application of using residuals from catch-curve regressions to assess year-class strength in fish. Fisheries Research 32:115-121.

Messenger, T. 1997. Water-quality assessment of the Kanawha-New River basin, West Virginia, and North Carolina - Review of water-quality literature through 1996. USGS Water Resource Investigations Report 97-4075.

Nash, M. K., and E. R. Irwin. 1999. Use of otoliths versus pectoral spines for aging adult flathead catfish. Pages 309-316 in E. R. Irwin, W. A. Hubert, C. F. Rabeni, H. L. Schramm, Jr., and T. Coon, editors. Catfish 2000: Proceedings of the International Ictalurid Symposium. American Fisheries Society, Symposium 24, Bethesda, Maryland.

Nifong, J. C., and B. R. Silliman, 2013. Impacts of a large-bodied, apex predator (Alligator mississippiensis Daudin 1801) on salt marsh food webs. Journal of Experimental Marine Biology and Ecology 440:185-191. 
Noble, R. L., and T. W. Jones. 1993. Managing fisheries with regulations. Pages 383-402 in C.C. Kohler and W.A. Hubert, editors. Inland fisheries management in North America. American Fisheries Society, Bethesda, Maryland.

Olive, J., H. L. Schramm, Jr., P. D. Gerard and E. R. Irwin. 2011. An evaluation of agreement between pectoral spines and otoliths for estimating ages of catfishes. Pages 679-688 in P. H. Michaletz and V. H. Travnichek, editors. Conservation, Ecology, and Management of Catfish: the Second International Symposium. American Fisheries Society, Symposium 77, Bethesda, Maryland.

ORSANCO (Ohio River Valley Water Sanitation Commission). 2013. Ohio River pool assessments. ORSANCO, Cincinnati, Ohio.

Owens, N. V. 2019. Distribution and habitat use of benthic fishes in the lower Kanawha River, West Virginia. Master's Thesis. West Virginia University, Morgantown, West Virginia.

Pearson, W. D., and B. J. Pearson. 1989. Fishes of the Ohio River. The Ohio Journal of Science 89(5):181-187.

Ricker, W. E. 1975. Computation and interpretation of biological statistics of fish populations. Fisheries Research Board of Canada Bulletin 191.

Schmitt, J. D., and D. E. Shoup. 2013. Delayed hooking mortality of Blue Catfish caught on juglines. North American Journal of Fisheries Management 33:245-252.

Seibert, K. L., J. R. Seibert, and Q. E. Phelps. 2017. Age-0 Blue Catfish habitat use and population demographics in the middle Mississippi River. Fisheries Management and Ecology 24:427-435.

Slipke, J. W., and M. J. Maceina. 2014. Fisheries Analysis and Modeling Simulator (FAMS), version 1.64. American Fisheries Society, Bethesda, Maryland.

Smith, N. G., D. J. Daugherty, E. L. Brinkman, M. G. Wegener, B. R. Kreiser, A. M. Ferrara, K. D. Kimmel, and S. R. David. 2020. Advances in the conservation and management of the Alligator Gar: a synthesis of current knowledge and introduction to a special section. North American Journal of Fisheries Management 40:527-543.

Stewart, D. R., G. W. Benz, and G. D. Scholten. 2009. Weight-length relationships and growth data for blue catfish from four Tennessee waterbodies. Proceedings of the Annual Conference Southeastern Association of Fish and Wildlife Agencies 63:140-146.

Trautman, M. B. 1981 The Fishes of Ohio. Ohio State University Press, Columbus, Ohio.

Van Hassel, J. H., R. J. Reash, H. W. Brown, J. L. Thomas, and R. C. Matthews, Jr. 1988. Distribution of upper and middle Ohio River fishes, 1973-85: I. Associations with water quality and ecological variables. Journal of Freshwater Ecology 4:441-458.

von Bertalanffy, L. 1938. A quantitative theory of organic growth. Human Biology 10:181-213. 


\section{Tables:}

Table 1. Record of Blue Catfish stocked by the West Virginia Division of Natural Resources within the R. C. Byrd Pool. An asterisk indicates fish held overwinter to attain a larger size before stocking.

\begin{tabular}{|c|c|c|c|}
\hline $\begin{array}{c}\text { Date } \\
\text { Stocked }\end{array}$ & $\begin{array}{c}\text { Fingerlings } \\
\text { Stocked }\end{array}$ & $\begin{array}{c}\text { Broodstock } \\
\text { Source }\end{array}$ & $\begin{array}{l}\text { Stocking } \\
\text { Location }\end{array}$ \\
\hline $11 / 11 / 2004$ & 4283 & Kentucky & Buffalo \\
\hline $11 / 11 / 2004$ & 4385 & Kentucky & Mason \\
\hline 4/12/2006 & 852 & Kentucky & Mason \\
\hline $10 / 31 / 2006$ & 4542 & Kentucky & Buffalo \\
\hline $10 / 31 / 2006$ & 4540 & Kentucky & Mason \\
\hline $11 / 14 / 2008$ & 7000 & Arkansas & Mason \\
\hline $11 / 17 / 2008$ & 10142 & Kentucky & Buffalo \\
\hline $11 / 17 / 2008$ & 10130 & Kentucky & Cheshire \\
\hline $3 / 24 / 2009$ & $150 *$ & Kentucky & Mason \\
\hline $10 / 27 / 2009$ & 14486 & Arkansas & Leon \\
\hline $10 / 27 / 2009$ & 13858 & Arkansas & Mason \\
\hline $9 / 28 / 2010$ & 17434 & Kentucky & Buffalo \\
\hline $9 / 28 / 2010$ & 17042 & Kentucky & Mason \\
\hline 9/30/2010 & 7804 & Kentucky & Syracuse \\
\hline $9 / 26 / 2011$ & 6054 & Kentucky & RCB Dam \\
\hline $9 / 26 / 2011$ & 27273 & Kentucky & Mason \\
\hline 9/28/2011 & 7549 & Kentucky & Buffalo \\
\hline 9/29/2011 & 5046 & Kentucky & Mason \\
\hline $10 / 10 / 2012$ & 18952 & Kentucky & Mason \\
\hline $10 / 11 / 2012$ & 10303 & Kentucky & Mason \\
\hline $10 / 12 / 2012$ & 9138 & Kentucky & Mason \\
\hline $9 / 24 / 2013$ & 10798 & Kentucky & Mason \\
\hline $9 / 25 / 2013$ & 9025 & Kentucky & Cheshire \\
\hline $9 / 25 / 2013$ & 9122 & Kentucky & Syracuse \\
\hline $10 / 21 / 2014$ & 15478 & Arkansas & Mason \\
\hline 9/30/2015 & 8127 & Arkansas & Leon \\
\hline $9 / 30 / 2015$ & 7821 & Arkansas & Mason \\
\hline
\end{tabular}


Table 2. CPUE (fish/hour) Blue Catfish collected during low frequency electrofishing surveys on the R. C. Byrd Pool from late May to early June 2017-2020. Fish are separated by Gabelhouse (1984) size classes by TL: Sub-stock $(<$ S), Stock (S), Quality (Q), Preferred (P), Memorable (M) and Trophy (T). Also included are mean values (Mean) along with 95\% Confidence Intervals (Mean \pm (2* Standard Error), negative values excluded).

\begin{tabular}{cccccccc}
\hline & & \multicolumn{6}{c}{ Size Class (mm) } \\
\multirow{2}{*}{ Year } & $<\mathrm{S}$ & $\mathrm{S}$ & $\mathrm{Q}$ & $\mathrm{P}$ & $\mathrm{M}$ & $\mathrm{T}$ & \\
\cline { 2 - 6 } & \multirow{2}{*}{300} & $300-$ & $510-$ & $760-$ & $890-$ & \multirow{2}{*}{ Total } & \\
\hline 2017 & 0.29 & 0.57 & 0.77 & 0.00 & 0.48 & 0.00 & 2.10 \\
2018 & 0.37 & 0.73 & 0.49 & 0.24 & 0.00 & 0.00 & 1.83 \\
2019 & 0.30 & 1.80 & 0.80 & 0.10 & 0.10 & 0.00 & 3.10 \\
2020 & 1.78 & 0.30 & 0.69 & 0.00 & 0.30 & 0.20 & 3.26 \\
& & & & & & & \\
Mean & 0.68 & 0.85 & 0.69 & 0.09 & 0.22 & 0.05 & 2.57 \\
95\% C.I. & $0-$ & $0.19-$ & $0.55-$ & $0-$ & $0.01-$ & $0-$ & $1.86-$ \\
\hline
\end{tabular}


Table 3. CPUE (fish/line night) of Blue Catfish collected during trotline surveys on the R.C. Byrd Pool during Winter 2017-2020. Trotlines contained 20 7/0 circle hooks per line and were baited with live gizzard shad (50-250 mm TL). Fish are separated by Gabelhouse (1984) size classes by TL: Sub-stock ( $<$ S), Stock (S), Quality (Q), Preferred (P), Memorable (M) and Trophy (T). Also included are mean values (Mean) along with 95\% Confidence Intervals (Mean \pm (2* Standard Error), negative values excluded).

\begin{tabular}{cccccccc}
\hline & \multicolumn{7}{c}{ Size Class $(\mathrm{mm})$} \\
& $<\mathrm{S}$ & $\mathrm{S}$ & $\mathrm{Q}$ & $\mathrm{P}$ & $\mathrm{M}$ & $\mathrm{T}$ & \\
\cline { 2 - 7 } Year & $<300$ & $300-$ & $510-$ & $760-$ & $890-$ & \multirow{2}{*}{$\geq 1140$} & \multirow{2}{*}{ Total } \\
\hline 2017 & 0.00 & 0.00 & 0.72 & 0.12 & 0.78 & 0.06 & 1.68 \\
2018 & 0.00 & 0.00 & 0.40 & 0.20 & 0.14 & 0.00 & 0.74 \\
2019 & 0.00 & 0.02 & 1.12 & 0.16 & 0.20 & 0.06 & 1.56 \\
2020 & 0.00 & 0.00 & 0.58 & 0.12 & 0.14 & 0.04 & 0.88 \\
& & & & & & & \\
Mean & 0.00 & 0.01 & 0.71 & 0.15 & 0.32 & 0.04 & 1.22 \\
95\% C.I. & 0.00 & $0-$ & $0.40-$ & $0.11-$ & $0.01-$ & $0.03-$ & $0.75-$ \\
& & 0.02 & 1.02 & 0.19 & 0.63 & 0.07 & 1.69 \\
\hline
\end{tabular}




\section{Figures:}

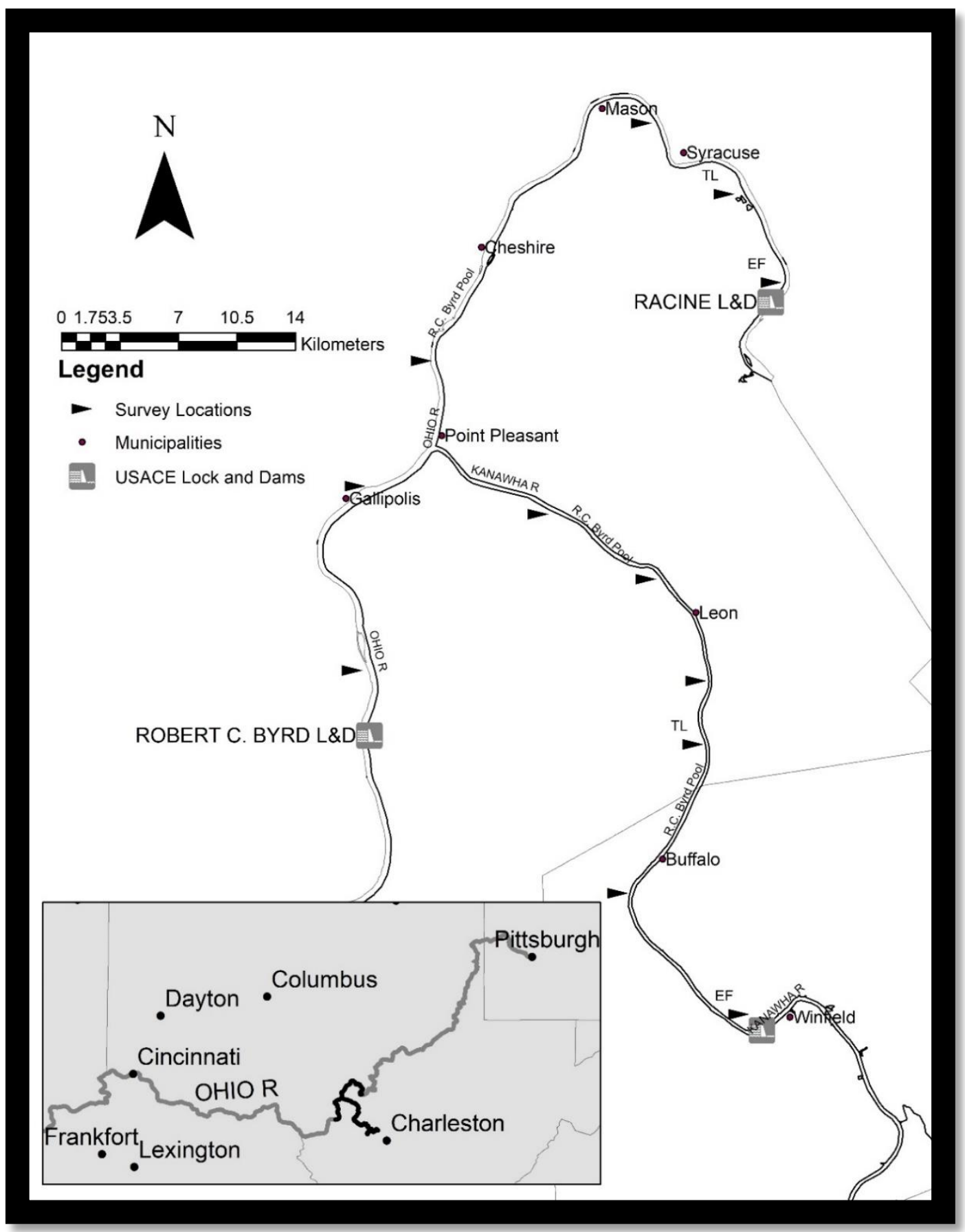

Figure 1. Map of the Robert C. Byrd Pool of the Ohio and Kanawha rivers near the vicinity of Point Pleasant, West Virginia. Survey locations labeled EF and TL were only sampled with electrofishing and trotlining, respectively. Major towns and stocking locations are included as municipalities. The pool boundaries are defined by the Robert C. Byrd, Racine, and Winfield locks and dams. 


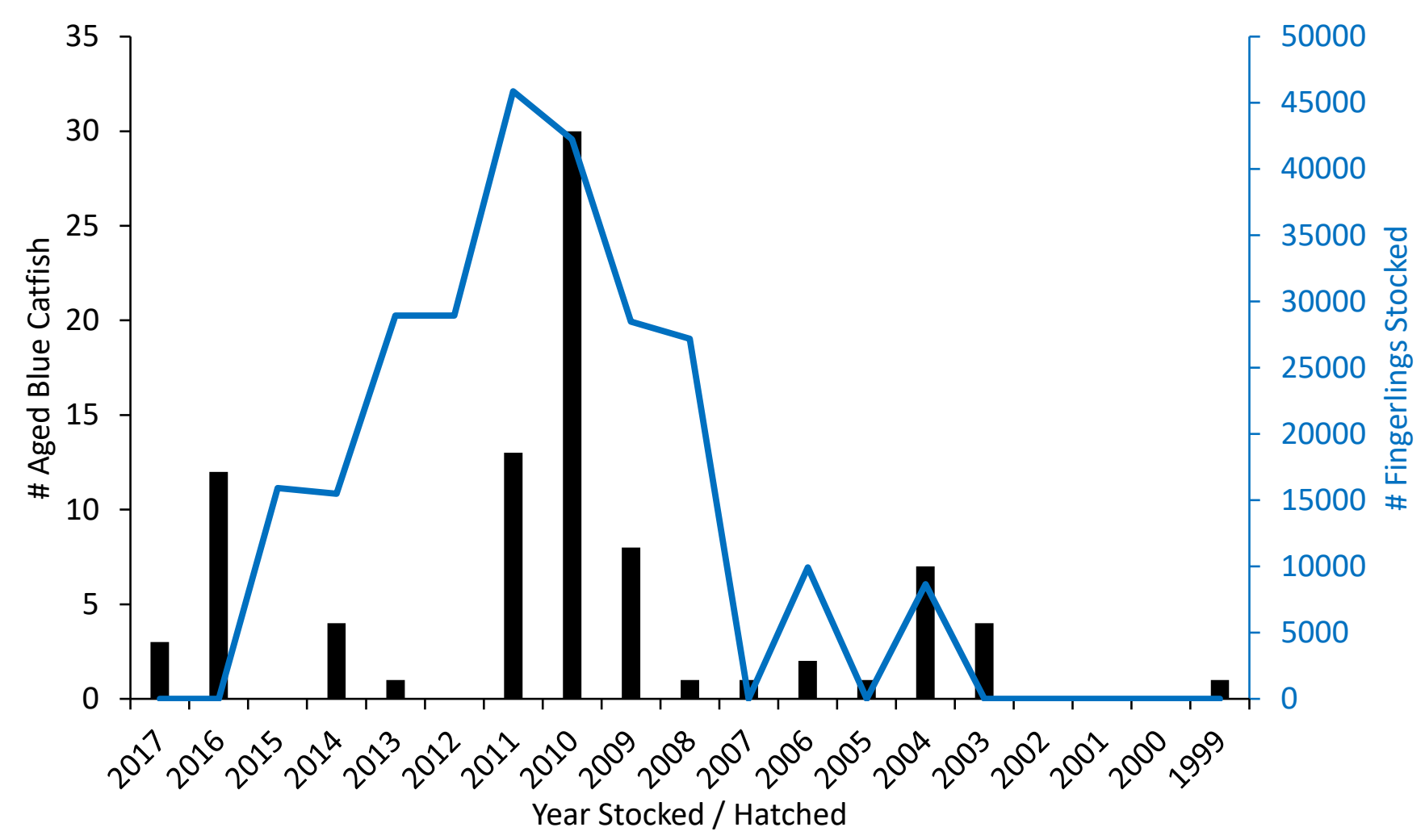

Figure 2. Left Axis: Age Frequency of Blue Catfish collected from the R.C. Byrd Pool by electrofishing and trotlining. Ages, represented by hatch year, were calculated by subtracting the age estimates for electrofished individuals from 2019 and age estimates for trotlined individuals from 2020, due to aging methodology. Right Axis: Number of Blue Catfish fingerlings stocked by the WVDNR within the R.C. Byrd Pool per year. 


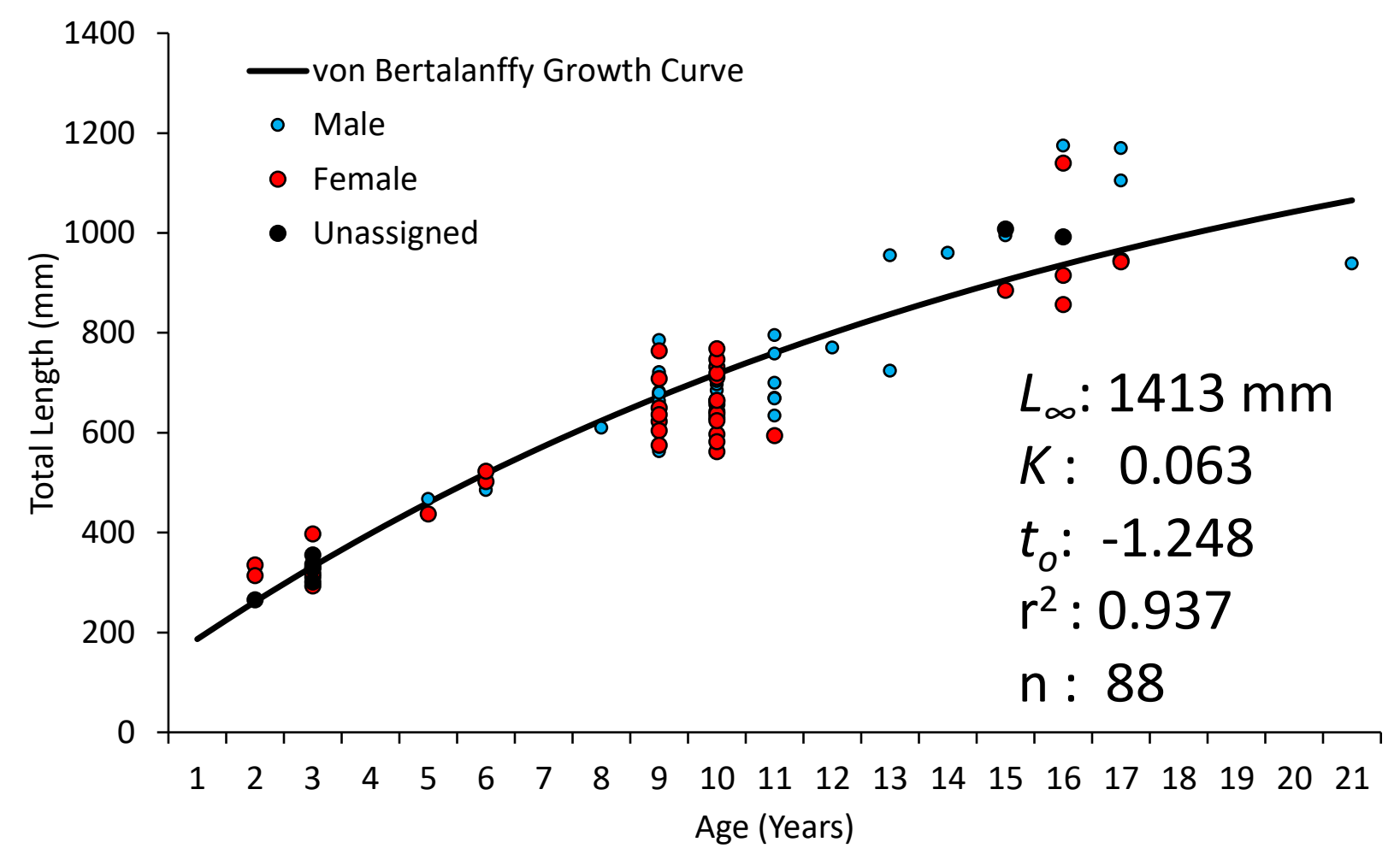

Figure 3. Length at age data by sex and population-wide von Bertalanffy growth curve for Blue Catfish collected from the R.C. Byrd Pool by electrofishing and trotlining. Von Bertalanffy growth parameters and sample size are displayed in bottom right of the figure. 


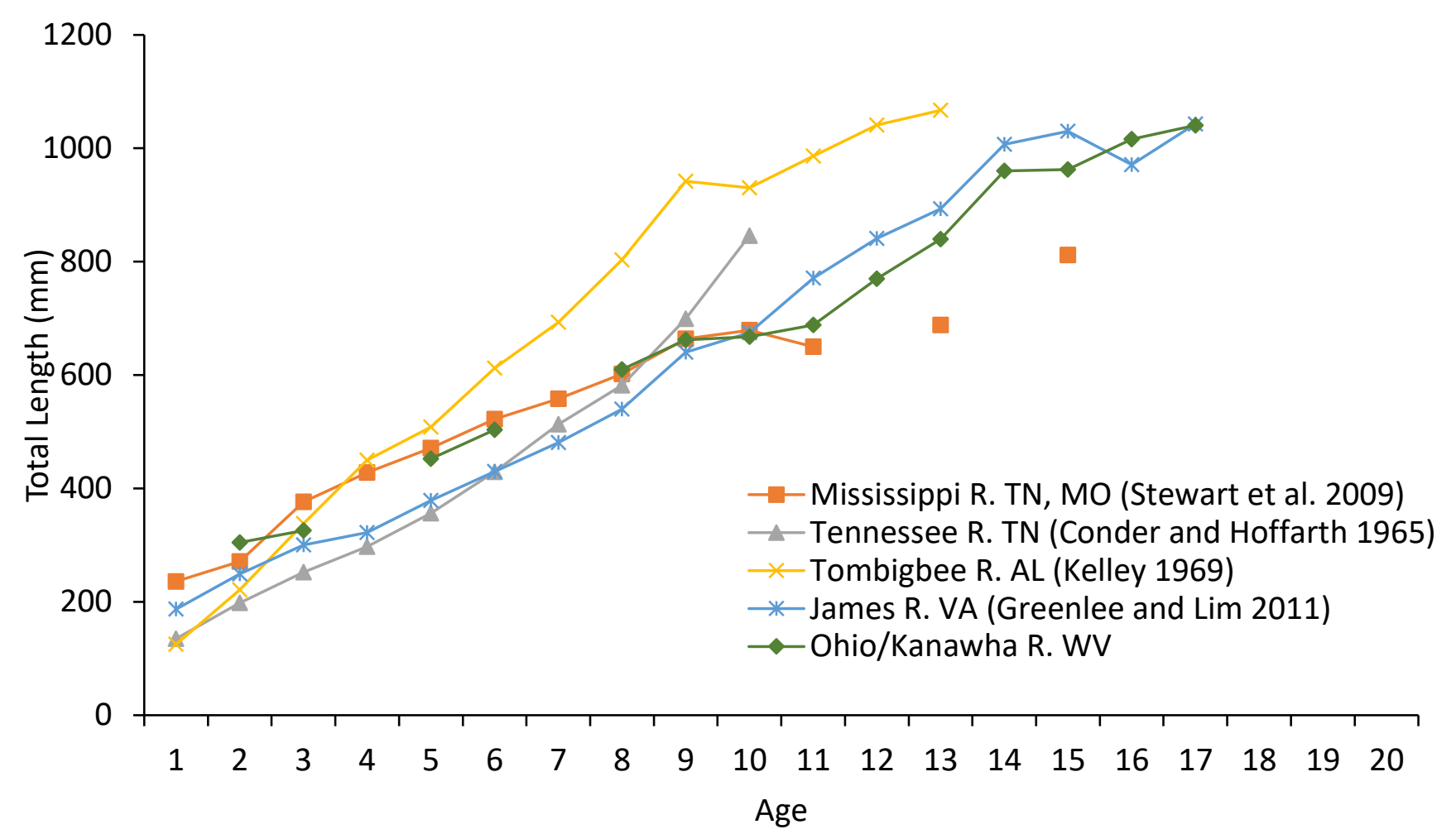

Figure 4. Mean length at age values from this study (Ohio/Kanawha R. WV) and those from published riverine Blue Catfish growth studies. 


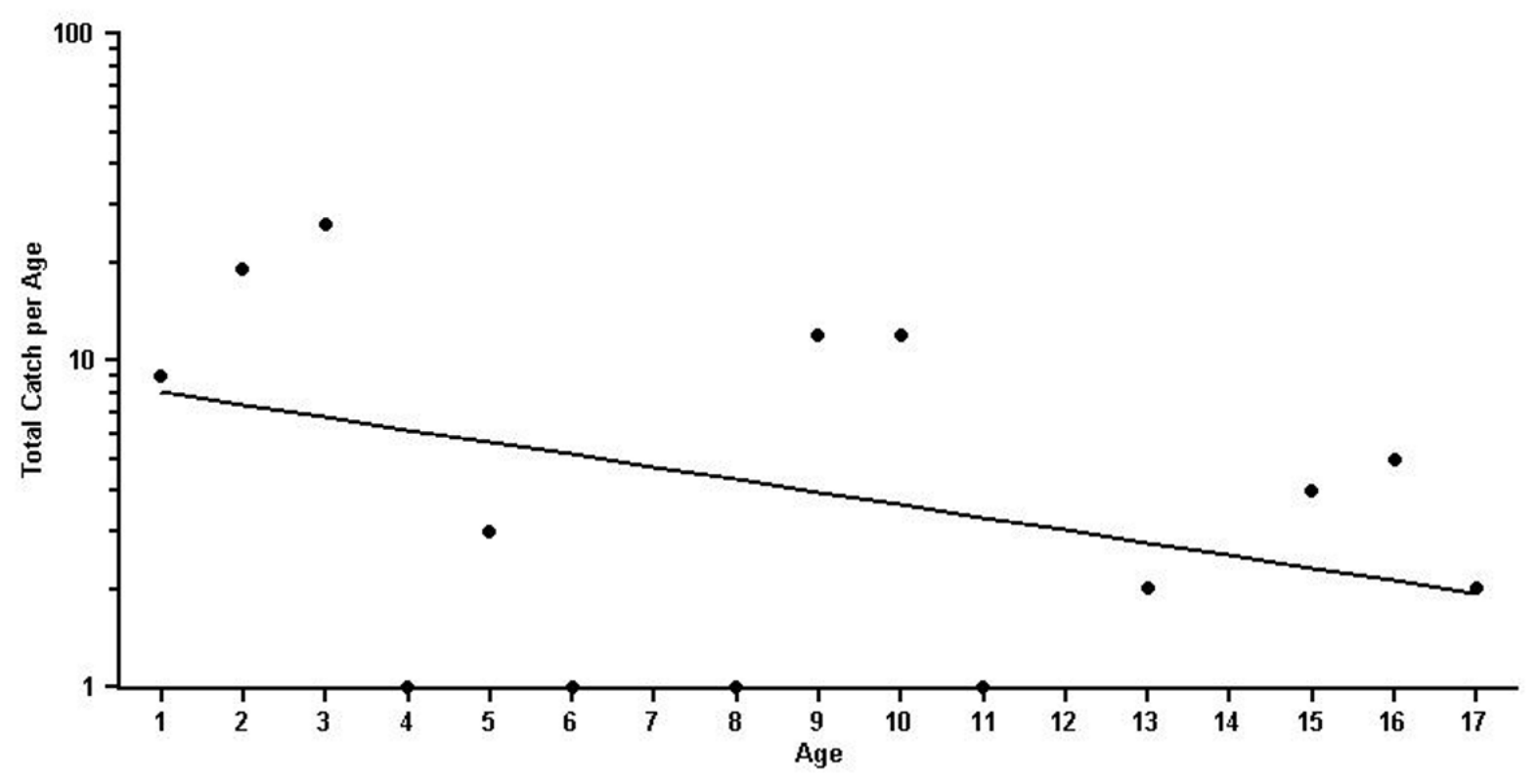

Figure 5. Catch curve using all Blue Catfish collected electrofishing $(\mathrm{n}=98)$. Unaged fish were assigned ages using an age-length key ( $25 \mathrm{~mm}$ groups). Fish with unassigned ages were assigned the age produced from the von Bertalanffy growth function. Estimated annual mortality $=0.085$, $r^{2}=0.164$ 


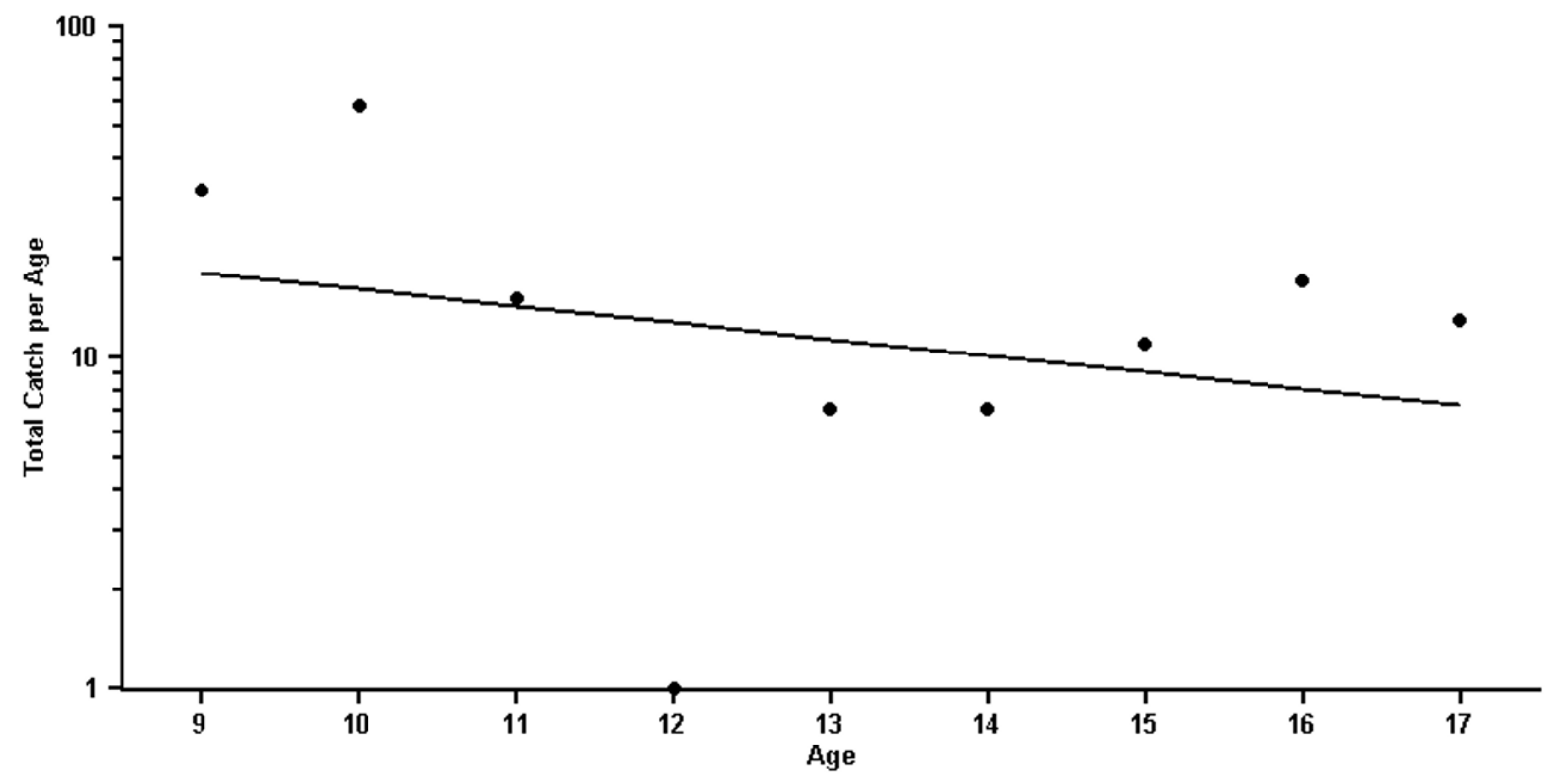

Figure 6. Catch curve using age 9+ Blue Catfish collected trotlining $(n=161)$. Unaged fish were assigned ages using an age-length key ( $25 \mathrm{~mm}$ groups). Fish with unassigned ages were assigned the age produced from the von Bertalanffy growth function. Estimated annual mortality $=0.11$, $\mathrm{r}^{2}=0.0741$. 


\section{Chapter 3: Size Structure, Age, Growth, and Mortality of Flathead Catfish within the Robert C. Byrd Pool of the Ohio and Kanawha Rivers}

\section{Introduction}

The Flathead Catfish (Pylodictis olivaris) is a large bodied, apex predator, native to the Mississippi River drainage, where it occurs commonly in low gradient, riverine environments or reservoirs (Jackson 1999). Flathead Catfish are targeted by recreational anglers and commercial fishers and are particularly sought after by trophy fishermen (Arterburn et al. 2002). For these reasons, there has been increasing focus on the ecology (Minckley and Deacon 1959; Gholson 1975; Lee and Terrell, 1988), population dynamics (Mayo and Schramm 1999; Jones and Noltie 2007), and capture efficiency (Stauffer and Koenen 1999; Vokoun and Rabeni 1999; Travnichek 2011; Ford et al. 2011; Gelwicks and Steuck 2011; Bodine et al. 2013) of this species in both lentic and lotic environments. The Flathead Catfish is an emerging sportfish of interest to managers, given that this species is increasingly targeted by anglers (Kwak et al. 2011). Some of the first steps toward management of Flathead Catfish fisheries involve establishing baseline information of the target population including catch rates, growth rates, and age data (Cleary and Greenbank 1954; Ricker 1975).

In this study, we examined the Flathead Catfish population within the Robert C. Byrd Pool of the Ohio and Kanawha Rivers. This large two-river system is unique, in part, because it does not support a commercial fishery. Flathead Catfish are native to and naturally reproducing in the study area and represent a popular fishery for regional anglers. The Robert C. Byrd Pool, along with the rest of the West Virginia sections of the Ohio and Kanawha rivers, is managed through regulations allowing the harvest of four Flathead Catfish per day, with only one over 35 inches $(889 \mathrm{~mm})$. Although Flathead Catfish populations have been studied extensively 
elsewhere, no publications have examined the population characteristics of this species in the West Virginia section of the Ohio River. Specifically, data on population characteristics, including size structure information, von Bertalanffy growth parameters, and mortality estimates are needed to inform management decisions for this fishery in the Robert C. Byrd Pool.

The goal of this study is to provide baseline population characteristics to guide future management decisions and fill a regional knowledge gap in the population ecology of Flathead Catfish. Study objectives include (1) identifying size structure through examination of catch rates, (2) determining growth rates using von Bertalanffy regression, and (3) estimating annual mortality through catch curve analysis.

\section{Methods:}

\section{Study Area}

The Robert C. Byrd Pool consists of the 61-km stretch of the middle Ohio River, between the Racine and Robert C. Byrd dams, as well as the lowest $51 \mathrm{~km}$ of the Kanawha River, below Winfield dam, which flows into the Ohio River near the town of Point Pleasant, WV (Figure 1). A minimum depth of $1.5 \mathrm{~m}$ is maintained by the U.S. Army Corps of Engineers to accommodate freight barges. Within the study area, the Ohio and Kanawha rivers average $8 \mathrm{~m}$ in depth, and are low gradient with sand, silt and clay substrate predominating (ORSANCO 2013). Revetments are common along riparian areas, particularly near urban and industrial areas. Water clarity ranged from high turbidity to approximately 0.5-m Secchi depth during our surveys.

\section{Electrofishing}

We conducted annual electrofishing surveys designed off the recommendations by Bodine et al. (2013). We used low frequency electrofishing (Smith Root GPP 5.0, 15 Hz, 200V), 
the most common method for sampling Flathead Catfish, as it provides the highest catch rates in lotic environments (Ford et al. 2011; McCain et al. 2011). There are currently no studies specifically addressing the size selectivity of this gear, however hoop nets have been found to catch a greater proportion of larger individuals (Ford et al. 2011; Gelwicks and Steuck 2011) leading to the conclusion that low frequency electrofishing selects against Flathead Catfish over $600 \mathrm{~mm}$ (Bodine et al. 2013). We surveyed in late May to early June 2017-2020. Surveys were conducted when water temperatures were above $20^{\circ} \mathrm{C}$ during low to moderate flows, environmental conditions associated with highest catch rates (Travnichek 2011). Sampling locations were selected with input from local anglers, and included outside bends, rip-rap banks, steep drop offs, and tailwaters. We surveyed two sites per day from late morning into the afternoon. We ran four 15-minute transects per site, motoring the electrofishing boat downstream approximately $10 \mathrm{~m}$ from the bank. We also employed a single chase boat to increase catch rates (Daugherty and Sutton 2005).

\section{Trotlining}

Due to the potential bias of electrofishing, we incorporated trotline surveys into our study design to sample larger sized fish. Although trotline use is rarely reported in the literature, this gear has been shown to select for the largest individuals in a population, potentially revealing the trophy potential within this system (Stauffer and Koenen 1999). We designed the survey using the same 10 sites as the electrofishing survey, however we moved tailwater sites downstream (approximately $1-20 \mathrm{~km}$ ) of dams to the next targeted habitat, owing to safety concerns associated with swift currents.

We trotlined during the fall and winter months to increase catch rates for Blue Catfish (Ictalurus furcatus), another species of interest during our study. We changed survey dates 
halfway through the four-year study. Initially, we surveyed in late November - early December in 2017 and 2018, then changed to January 2020-2021 (referred to as the 2019-2020 surveys) due to scheduling conflicts. The effects of this shift timing are evident in catch data, and addressed in the discussion.

Each trotline set consisted of a set of 3 weights and 2 floats, equipped with 20 7/0 Eagle Claw Lazer Sharp Circle Sea hooks. Live Gizzard Shad (50-300 mm TL) were used to bait the hooks, and were caught by electrofishing in an embayment within the study area the day of sampling. We chose to use live Gizzard Shad as bait, because this species constitutes the largest biomass of fish in the pool and is a natural forage for Flathead Catfish. We set 5 lines off the bank at each site, ensuring the first hook was set at a depth greater than $3 \mathrm{~m}$. We fished the lines overnight.

\section{Age and Growth}

For age analysis, we used four randomly selected Flathead Catfish from each transect during our 2019 electrofishing survey. This was done to get a representative sample of ages in response to reports of variable length at age in other West Virginia populations. Although pectoral spines are a valid measure of Flathead Catfish age (Olive et al. 2011) and have been validated to age 5 (Turner 1980), we utilized lapilli otoliths for aging (Long and Stewart 2010). Otoliths have been found to agree with pectoral spines up to age 5 (Nash and Irwin 1999) and are significantly more accurate past age 17 (Olive et al. 2011; Steuck and Schnitzler, 2011). Accuracy at older ages is important due to reports of exceptionally long-lived Flathead Catfish in West Virginia (Nate Taylor, WVDNR, personal communication). 
We extracted and aged our otoliths using the methodology from Buckmeier et al. (2002), with several modifications. To diminish the chances of obscuring annuli, we did not burn otoliths on a hot plate prior to mounting. We used a dissecting microscope with camera to photograph annuli. We incrementally sanded each otolith to its core, taking multiple photographs as we progressed. We submerged the mounted otoliths in water instead of mineral oil for photographs and found adequate contrast between annuli. Two independent readers estimated age by counting annuli from the images, reconciling disagreements via concert readings.

\section{Data Analysis}

We counted and measured total length $(\mathrm{mm})$ of all Flathead Catfish collected during our surveys. We calculated CPUE as number of fish per hour (fish / hr) and number of fish per line night (fish / line night) for electrofishing and trotlining, respectively. We estimated size structure by comparing electrofishing CPUE through size classes (mm) defined by Gabelhouse (1984): Sub-stock <350, Stock 350-510, Quality 510-710, Preferred 710-860, Memorable 860-1020, and Trophy $>1020$. We calculated mean annual CPUE values as well as 95\% Confidence Intervals by $2 *$ standard error. We compared our catch data to a hypothesized population experiencing constant recruitment and mortality to infer population dynamics.

We sexed our subset of aged individuals through dissection and visual inspection of the gonads. We compared ages between sexes graphically. We modeled growth using the Fisheries Analysis and Modeling Simulator (FAMS; Slipke and Maceina 2014), with ages from individuals obtained through both gears. We solved for the von Bertalanffy (1938) parameters in the equation:

$$
L_{t}=L_{\infty}\left(1-\mathrm{e}^{-k(t-t o)}\right)
$$


where: $L_{\infty}=$ maximum theoretical length (length infinity) that can be obtained; $k=$ growth coefficient; $t=$ time or age in years; $t o=$ is the time in years when length would theoretically be equal to zero and; e = exponent for natural logarithms.

We calculated mean length at age values in FAMS. Results were plotted with similar data from riverine Flathead Catfish populations within their native range for comparison (Stauffer et al. 1996 from: Kwak et al. 2006; Robinson et al. 1997; Nash 1999; Steuck and Schnitzler, 2011). We assigned ages to all fish collected by using FAMS and the weighted average probability methodology in the Age-Length key function (25 mm size bins). Fish not receiving ages were assigned the age estimated from the von Bertalanffy growth function. We constructed a catch curve (Ricker 1974) in FAMS for electrofishing, using the weighted regression function to estimate mortality (Maceina 1997). We included ages 1 to 23 in the analysis, as we collected few fish of age 0 or age $>23$.

\section{Results}

We captured a total of 1893 Flathead Catfish electrofishing. Total CPUE values ranged from 29.73 in 2018 to 80.61 in 2020 (Table 1). The mean total CPUE $47.93 \pm 22.40$ (fish/hr) was higher than those reported in Bodine et al. (2013). We collected all size classes every year except in 2018, where we did not capture any trophy individuals. Size structure was consistent with that expected of a theoretical population with constant recruitment and mortality, with our mean catch rates decreasing with increasing size class. Sub-stock CPUE was very high during the 2020 sample year (52.79 fish/hr). We observed a large (4.99 fish/hr) decrease in catch rates from quality to preferred and larger size fish. 
We collected 102 Flathead Catfish during our trotline surveys. We observed a large difference in total catch rate between 2017-2018 (mean $=0.13$ fish/line night) and 2019-2020 $($ mean $=1.05$ fish/line night) surveys, correlating with the change in survey date (Table 2). Catches increased from sub-stock to quality size, then decreased from preferred size and larger size classes. We collected four stock size and zero sub-stock fish total.

We successfully aged 143 of the 154 Flathead Catfish collected for aging. We observed similar growth between sexes, with a total age range of 0 to 36 years old (Figure 2). We observed with variable growth, seen as a large divergence from our von Bertalanffy growth curve, particularly in ages 10+ (Figure 2). We found the R.C. Byrd population's growth rates to be below average when compared to data published for other populations (Figure 3). Our catch curve indicated low mortality in the population, with an annual mortality estimate of 0.126 (Figure 4).

\section{Discussion}

The results from this study suggest that the Robert C. Byrd Pool supports a robust population of Flathead Catfish. In general terms, this population is characterized by long-lived and slow-growing individuals within a stable, high-density population experiencing low mortality. This indicates the presence of quality habitat for all life stages within the pool. This is encouraging considering the poor environmental history of the Ohio (ORSANCO 1962) and Kanawha Rivers (Messenger 1997). These results also forecast the continued quality of this popular recreational fishery.

Our electrofishing CPUE data indicate this population's size structure, which decreased with increasing size during three of four annual electrofishing surveys. This is indicative of a 
population not undergoing acute fluctuations, such as those caused by competition with an emerging Blue Catfish population within the study area. Further, high catches of sub-stock individuals in the 2020 electrofishing survey suggest one or more substantial year classes recruiting into the fishery. The notable decrease in catch rates from quality to preferred and larger size fish $(>710 \mathrm{~mm})$, roughly correlated with the estimated gear bias against fish larger than $600 \mathrm{~mm}$ (Bodine et al. 2013).

Our trotlining CPUE by size distribution is best explained by the biases associated with 7/0 circle hooks and change in annual survey date. The increasing catch rates to preferred size represent a gradual recruitment to the gear, a function of hooking efficiency to gape size. We estimate the 7/0 circle hooks are most effective on Flathead Catfish $700 \mathrm{~mm}$ and larger. We assume trotline catches are largely unbiased at larger sizes, barring diet or behavioral shifts at these sizes. The effects of water temperature and metabolism effects on foraging may explain the catch rate differential between the 2017-2018 and 2019-2020 surveys, but we did not measure the metabolic condition of fish during this study.

The slow growth seen in this population could be related to high densities, as supported by high electrofishing catch rates. Specifically, high densities of Flathead Catfish could lead to intraspecific competition for food. Length of growing season does not appear to be a major contributing factor to our growth rates, as the fastest growth was found in the Minnesota River, MN (Stauffer et al. 1996), and the slowest growth from the Tallapoosa River, AL, which was attributed to low productivity in the system (Nash 1999). Variation in growth in older Flathead Catfish was also documented for the Mississippi River, IA (Steuck and Schnitzler 2011), where the authors attributed the variability to a low sample size of age fish with ages $12-26$. In our study, sample size does not address the high residuals found on both sides of our von Bertalanffy 
curve. This could be driven by environmental factors that support fast growth (Jones and Noltie 2007) during critical periods in certain cohorts, or individual behavioral factors such as variable predatory success or dominance hierarchies.

Our catch curve findings suggest low annual mortality within the study area, collaborated by our evidence of long-lived individuals. The $12 \%$ annual mortality estimate is very close to that found in the tailwater habitats of the Coosa River, AL (Jolley and Irwin 2011), and lower than those reported for other riverine Flathead Catfish populations (Robinson 1997; Kwak et al. 2006; Sakaris et al. 2006). Given that our catch curve used fish captured from electrofishing exclusively, our $12 \%$ annual mortality figure may be high due to electrofishing gear bias against larger fish. This low annual mortality supports our suspicions of low fishing mortality on the population, despite the fishery's popularity with anglers. We believe this is due to anglers' interest in catch and release fishing, potentially driven by a combination of consumption advisories and interest in preserving the population to produce trophy individuals. Additional studies are needed to examine the importance of catch and release hooking mortality on this Flathead Catfish fishery.

\section{Management Implications}

Management of the Flathead Catfish population within the Robert C. Byrd Pool is complicated by numerous factors. Low fishing mortality reduces the ability for harvest regulations to shape population structure. However, this low exploitation is beneficial to the slow growing, long lived population, as these characteristics make it vulnerable to growth overfishing. We recommend surveying angler attitudes towards this fishery, as a rapid change in angler sentiment toward harvest could result in long lasting negative impacts to the abundance of the larger size classes, harming trophy fishing opportunities. Angler preference toward harvesting 
mid- to large-sized Flathead Catfish in similar systems has been documented (Winders and McMullen 2020), increasing these concerns. Effects of similar harvest in this system would be mitigated by the current regulations; however, determining the extent of this requires careful population modeling for accurate predictions. 


\section{Literature Cited:}

Arterburn, J. E., D. J. Kirby, and C. R. Berry. 2002. A survey of angler attitudes and biologist opinions regarding trophy catfish and their management. Fisheries 27(5):10-21.

Bodine, K. A., D. E. Shoup, J. Olive, Z. L. Ford, R. Krogman, and T. J. Stubbs. 2013. Catfish sampling techniques: where we are now and where we should go. Fisheries 38:529-546.

Buckmeier, D. L., E. R. Irwin, R. K. Betsill, and J. A. Prentice. 2002. Validity of otoliths and pectoral spines for estimating ages of channel catfish. North American Journal of Fisheries Management 22:934-942.

Cleary, R. E., and J. Greenbank. 1954. An analysis of techniques used in estimating fish populations in streams, with particular reference to large non-trout streams. Journal of Wildlife Management 18:461-476

Daugherty, D. J., and T. M. Sutton. 2005. Use of a chase boat for increasing electrofishing efficiency for flathead catfish in lotic systems. North American Journal of Fisheries Management 25:1528-1532.

Ford, Z. L., K. P. Sullivan, I. W. Vining, T. G. Kulowiec, G. D. Pitchford, H. R. Dames, R. J. Dent, and E. Colvin. 2011. Sampling statistics and size distributions for Flathead Catfish populations in four Missouri Rivers. Pages 95-104 in P. H. Michaletz and V. H. Travnichek, editors. Conservation, Ecology, and Management of Catfish: the Second International Symposium. American Fisheries Society, Symposium 77, Bethesda, Maryland.

Gabelhouse, D. W., Jr. 1984. A length-categorization system to assess fish stocks. North American Journal of Fisheries Management 4:273-28.

Gelwicks, G. T. and M. J. Steuck. 2011. Evaluation of the status, distribution and habitats of flathead catfish in Iowa's rivers. Iowa Department of Natural Resources. Federal Aid in Sport Fish Restoration, Project F-160-R, Completion Report, Des Moines.

Gholson, K. W. 1975. Life history of the flathead catfish (Pylodictis olivaris). Texas Parks and Wildlife, Federal Aid Project F-31-R-1, Annual Report, Austin.

Jackson, D. C. 1999. Flathead catfish: biology, fisheries, and management. Pages 23-35 in E. R. Irwin, W. A. Hubert, C. F. Rabeni, H. L. Schramm, Jr., and T. Coon, editors. Catfish 2000: Proceedings of the International Ictalurid Symposium. American Fisheries Society, Symposium 24, Bethesda, Maryland.

Jolley, J. C., and E. R. Irwin. 2011. Catfish population characteristics in tailwater and reservoir habitats of the Coosa River, Alabama. Pages 155-166 in P. H. Michaletz and V. H. Travnichek, editors. Conservation, Ecology, and Management of Catfish: the Second International Symposium. American Fisheries Society, Symposium 77, Bethesda, Maryland.

Jones, B. D., and D. B. Noltie. 2007. Flooded flatheads: evidence of increased growth in Mississippi River Pylodictis olivaris (Pisces: Ictaluridae) following the great midwest flood of 1993. Hydrobiologia 592:183-209. 
Kwak, T. J., W. E. Pine, III, and D. S. Waters. 2006. Age, growth, and mortality of introduced flathead catfish in Atlantic rivers and a review of other populations. North American Journal of Fisheries Management 26:73-87.

Kwak, T. J., M. T. Porath, P. H. Michaletz, and V. H. Travnichek. 2011. Catfish science: status and trends in the 21st century. Pages 755-780 in P. H. Michaletz and V. H. Travnichek, editors. Conservation, Ecology, and Management of Catfish: the Second International Symposium. American Fisheries Society, Symposium 77, Bethesda, Maryland.

Lee, L. A., and J. W. Terrell. 1987. Habitat suitability index models: flathead catfish. Biological Report 82 (10.152). U.S. Department of the Interior, Fish and Wildlife Service, Research and Development, Washington, D.C.

Long, J. M., and D. R. Stewart. 2010. Verification of otolith identity used by fisheries scientists for aging channel catfish. Transactions of the American Fisheries Society 139:17751779.

Maceina M. J. 1997. Simple application of using residuals from catch-curve regressions to assess year-class strength in fish. Fisheries Research 32:115-121.

Maceina, M. J., J. Boxrucker, D. L. Buckmeier, R. S. Gangl, D. O. Lucchesi, D. A. Isermann, J. R. Jackson, and P. J. Martinez. 2007. Current status and review of freshwater fish aging procedures used by state and provincial fisheries agencies with recommendations for future directions. Fisheries 32:329-340.

Mayo, R. M., and H. L. Schramm, Jr. 1999. Growth of flathead catfish in the lower Mississippi River. Pages 121-124 in E. R. Irwin, W. A. Hubert, C. F. Rabeni, H. L. Schramm, Jr., and T. Coon, editors. Catfish 2000: Proceedings of the International Ictalurid Symposium. American Fisheries Society, Symposium 24, Bethesda, Maryland.

McCain, K. N. S., J. W. Ridings, Q. Phelps, and R. A. Hrabik. 2011. Population trends of Flathead Catfish, Channel Catfish, and Blue Catfish in impounded and unimpounded reaches of the upper Mississippi River (1993-2007). Pages 141-154 in P. H. Michaletz and V. H. Travnichek, editors. Conservation, Ecology, and Management of Catfish: the Second International Symposium. American Fisheries Society, Symposium 77, Bethesda, Maryland.

Messenger, T. 1997. Water-quality assessment of the Kanawha-New River basin, West Virginia, and North Carolina - Review of water-quality literature through 1996. USGS Water Resource Investigations Report 97-4075.

Minckley, W. L., and J. E. Deacon. 1959. Biology of the flathead catfish in Kansas. Transactions of the American Fisheries Society 88:344-355.

Nash, M. K. 1999. Age and growth of flathead catfish and channel catfish in the Tallapoosa River, Alabama, and the Ocmulgee River, Georgia. Master's thesis. Auburn University, Auburn, Alabama.

Nash, M. K., and E. R. Irwin. 1999. Use of otoliths versus pectoral spines for aging adult flathead catfish. Pages 309-316 in E. R. Irwin, W. A. Hubert, C. F. Rabeni, H. L. 
Schramm, Jr., and T. Coon, editors. Catfish 2000: Proceedings of the International Ictalurid Symposium. American Fisheries Society, Symposium 24, Bethesda, Maryland.

Olive, J., H. L. Schramm, Jr., P. D. Gerard and E. R. Irwin. 2011. An evaluation of agreement between pectoral spines and otoliths for estimating ages of catfishes. Pages 679-688 in P. H. Michaletz and V. H. Travnichek, editors. Conservation, Ecology, and Management of Catfish: the Second International Symposium. American Fisheries Society, Symposium 77, Bethesda, Maryland.

ORSANCO (Ohio River Valley Water Sanitation Commission). 1962. Aquatic-life resources of the Ohio River. ORSANCO, Cincinnati, Ohio.

ORSANCO (Ohio River Valley Water Sanitation Commission). 2013. Ohio River pool assessments. ORSANCO, Cincinnati, Ohio.

Robinson, J. W. 1997. The development of a qualitative system to evaluate populations of channel catfish and flathead catfish in the Missouri and Mississippi rivers. Missouri Department of Conservation, Final Report, Project F-1-R-46, Columbia.

Ricker, W. E. 1975. Computation and interpretation of biological statistics of fish populations. Fisheries Research Board of Canada Bulletin 191.

Sakaris, P. C., E. R. Irwin, J. C. Jolley, and D. H. Harrison. 2006. Comparison of native and introduced flathead catfish populations in Alabama and Georgia: growth, mortality, and management. North American Journal of Fisheries Management 26:867-874.

Slipke, J. W., and M. J. Maceina. 2014. Fisheries Analysis and Modeling Simulator (FAMS), version 1.64. American Fisheries Society, Bethesda, Maryland.

Stauffer, K. W., R. C. Binder, B. C. Chapman, and B. D. Koenen. 1996. Population characteristics and sampling methods of flathead catfish Pylodictis olivaris in the Minnesota River. Minnesota Department of Natural Resources, Division of Fish and Wildlife, Section of Fisheries, Study IV, Job 389, St. Paul.

Stauffer, K. W., and B. D. Koenen. 1999. Comparison of methods for sampling Flathead Catfish in the Minnesota River. Pages 329-333 in E. R. Irwin, W. A. Hubert, C. F. Rabeni, H. L. Schramm, Jr., and T. Coon, editors. Catfish 2000: Proceedings of the International Ictalurid Symposium. American Fisheries Society, Symposium 24, Bethesda, Maryland.

Steuck, M. J. and C. C. Schnitzler. 2011. Age and growth of flathead catfish from pools 12 and 13 of the upper Mississippi River. Pages 699-712 in P. H. Michaletz and V. H. Travnichek, editors. Conservation, Ecology, and Management of Catfish: the Second International Symposium. American Fisheries Society, Symposium 77, Bethesda, Maryland.

Travnichek, V. H. 2011. Monthly variation and influences of habitat and river stage on electrofishing catch rates and population indices of Flathead Catfish from the lower Missouri River. Pages 621-635 in P. H. Michaletz and V. H. Travnichek, editors. Conservation, Ecology, and Management of Catfish: the Second International Symposium. American Fisheries Society, Symposium 77, Bethesda, Maryland. 
Turner, P. R. 1980. Procedures for age determination and growth rate calculations for flathead catfish. Proceedings of the Annual Conference Southeastern Association of Fish and Wildlife Agencies 34:253-262.

Vokoun, J. C., and C. F. Rabeni. 1999. Catfish sampling in rivers and streams: a review of strategies, gears, and methods. Pages 621-635 in E. R. Irwin, W. A. Huber, C. F. Rabeni, H. L. Schramm, Jr., and T. Coon, editors. Catfish 2000: Proceedings of the International Ictalurid Symposium. American Fisheries Society, Symposium 24, Bethesda, Maryland.

Winders, K. R., and J. A. McMullen. 2021. Size-specific exploitation of flathead catfish and blue catfish by recreational and commercial fishers in the Missouri and Mississippi Rivers, Missouri. North American Journal of Fisheries Management.

https://doi.org/10.1002/nafm.10619 


\section{Tables:}

Table 1. CPUE (fish/hour) Flathead Catfish collected during low frequency electrofishing surveys on the R. C. Byrd Pool from late May to early June 2017-2020. Fish are separated by Gabelhouse (1984) size classes by TL: Sub-stock $(<\mathrm{S})$, Stock (S), Quality (Q), Preferred (P), Memorable (M) and Trophy (T). Also included are mean values (Mean) along with 95\% Confidence Intervals (Mean $\pm(2 *$ Standard Error) negative values excluded).

\begin{tabular}{cccccccc}
\hline & \multicolumn{7}{c}{ Size Class $(\mathrm{mm})$} \\
\multirow{2}{*}{ Year } & $<\mathrm{S}$ & $\mathrm{S}$ & $\mathrm{Q}$ & $\mathrm{P}$ & $\mathrm{M}$ & $\mathrm{T}$ & \\
\cline { 2 - 7 } & \multirow{2}{*}{350} & $350-$ & $510-$ & $710-$ & $860-$ & \multirow{2}{*}{ Total } & \\
\hline 2017 & 15.98 & 11.96 & 8.51 & 2.58 & 0.77 & 0.29 & 40.09 \\
2018 & 14.01 & 6.22 & 7.19 & 2.07 & 0.24 & 0.00 & 29.73 \\
2019 & 25.01 & 7.00 & 6.60 & 1.70 & 0.70 & 0.20 & 41.30 \\
2020 & 52.79 & 11.94 & 11.05 & 3.75 & 0.79 & 0.30 & 80.61 \\
& & & & & & & \\
Mean & 26.97 & 9.28 & 8.34 & 2.53 & 0.62 & 0.20 & 47.93 \\
95\% C.I. & $9.09-$ & $6.18-$ & $6.36-$ & $1.64-$ & $0.36-$ & $0.06-$ & $25.53-$ \\
& 44.85 & 12.38 & 10.32 & 3.42 & 0.88 & 0.34 & 70.33 \\
\hline
\end{tabular}


Table 2. CPUE (fish/line night) of Flathead Catfish collected during trotline surveys on the R.C. Byrd Pool during November/December 2017-2018 and January 20202021 (referred to as 2019-2020 surveys). Trotlines contained 20 7/0 circle hooks per line and were baited with live gizzard shad (50-250 mm TL). Fish are separated by Gabelhouse (1984) size classes by TL: Sub-stock (<S), Stock (S), Quality (Q), Preferred (P), Memorable (M) and Trophy (T). Also included are mean values (Mean) along with $95 \%$ Confidence Intervals (Mean $\pm(2 *$ Standard Error), negative values excluded).

\begin{tabular}{|c|c|c|c|c|c|c|c|}
\hline \multirow[b]{3}{*}{ Year } & \multicolumn{6}{|c|}{ Size Class (mm) } & \multirow[b]{3}{*}{ Total } \\
\hline & $<\mathrm{S}$ & $\mathrm{S}$ & Q & $\mathrm{P}$ & $\mathrm{M}$ & $\mathrm{T}$ & \\
\hline & $<350$ & $\begin{array}{l}350- \\
509.9\end{array}$ & $\begin{array}{c}510- \\
709.9\end{array}$ & $\begin{array}{c}710- \\
859.9\end{array}$ & $\begin{array}{l}860- \\
1019\end{array}$ & $\geq 1020$ & \\
\hline 2017 & 0.00 & 0.00 & 0.36 & 0.46 & 0.14 & 0.08 & 1.04 \\
\hline 2018 & 0.00 & 0.00 & 0.40 & 0.51 & 0.14 & 0.00 & 1.06 \\
\hline 2019 & 0.00 & 0.08 & 0.04 & 0.02 & 0.00 & 0.00 & 0.14 \\
\hline 2020 & 0.00 & 0.00 & 0.02 & 0.02 & 0.06 & 0.02 & 0.12 \\
\hline Mean & 0.00 & 0.02 & 0.21 & 0.25 & 0.09 & 0.03 & 0.59 \\
\hline 95\% C.I. & 0.00 & $\begin{array}{c}0- \\
0.06\end{array}$ & $\begin{array}{c}0.01- \\
0.41\end{array}$ & $\begin{array}{c}0- \\
0.52\end{array}$ & $\begin{array}{c}0.02- \\
0.16\end{array}$ & $\begin{array}{c}0- \\
0.07\end{array}$ & $\begin{array}{c}0.06- \\
1.12\end{array}$ \\
\hline
\end{tabular}




\section{Figures:}

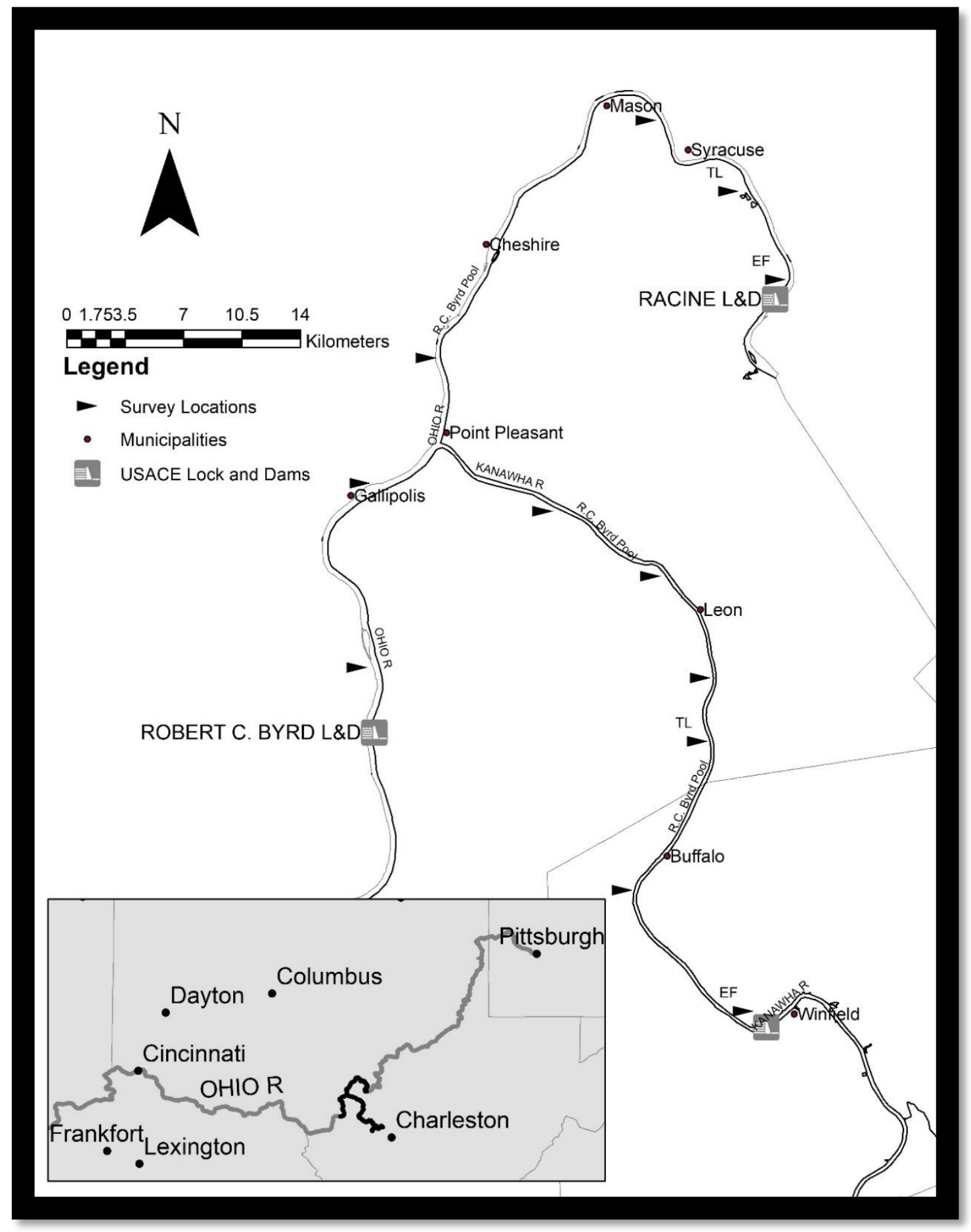

Figure 1. Map of the Robert C. Byrd Pool of the Ohio and Kanawha rivers near the vicinity of Point Pleasant, West Virginia. Survey locations labeled EF and TL were only sampled with electrofishing and trotlining, respectively. The pool boundaries are defined by the Robert C. Byrd, Racine, and Winfield locks and dams. 


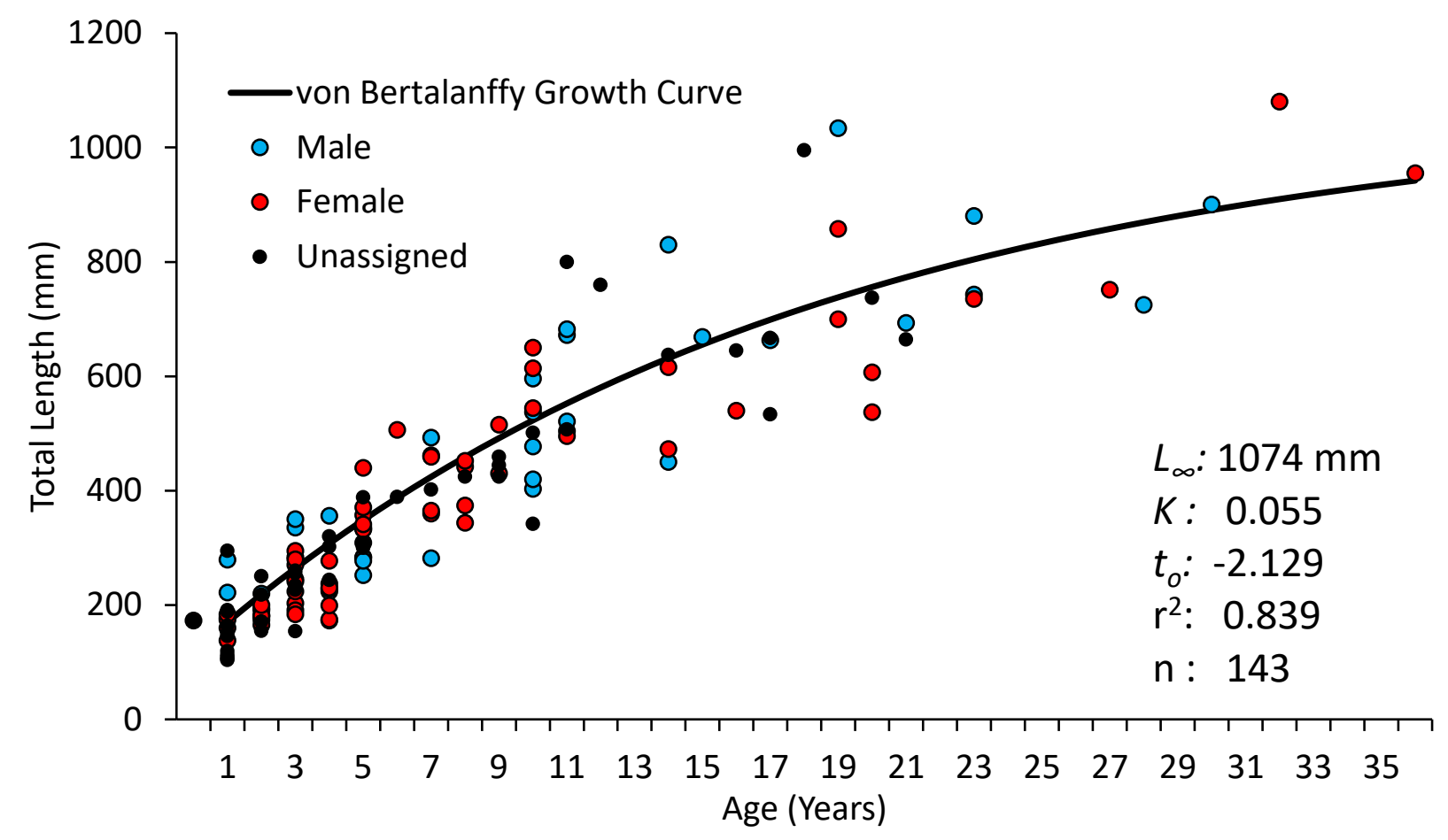

Figure 2. Length at age by sex and population-wide von Bertalanffy growth curve for Flathead Catfish collected from the R.C. Byrd Pool by electrofishing. Von Bertalanffy growth parameters and sample size are displayed in bottom right of the figure. 


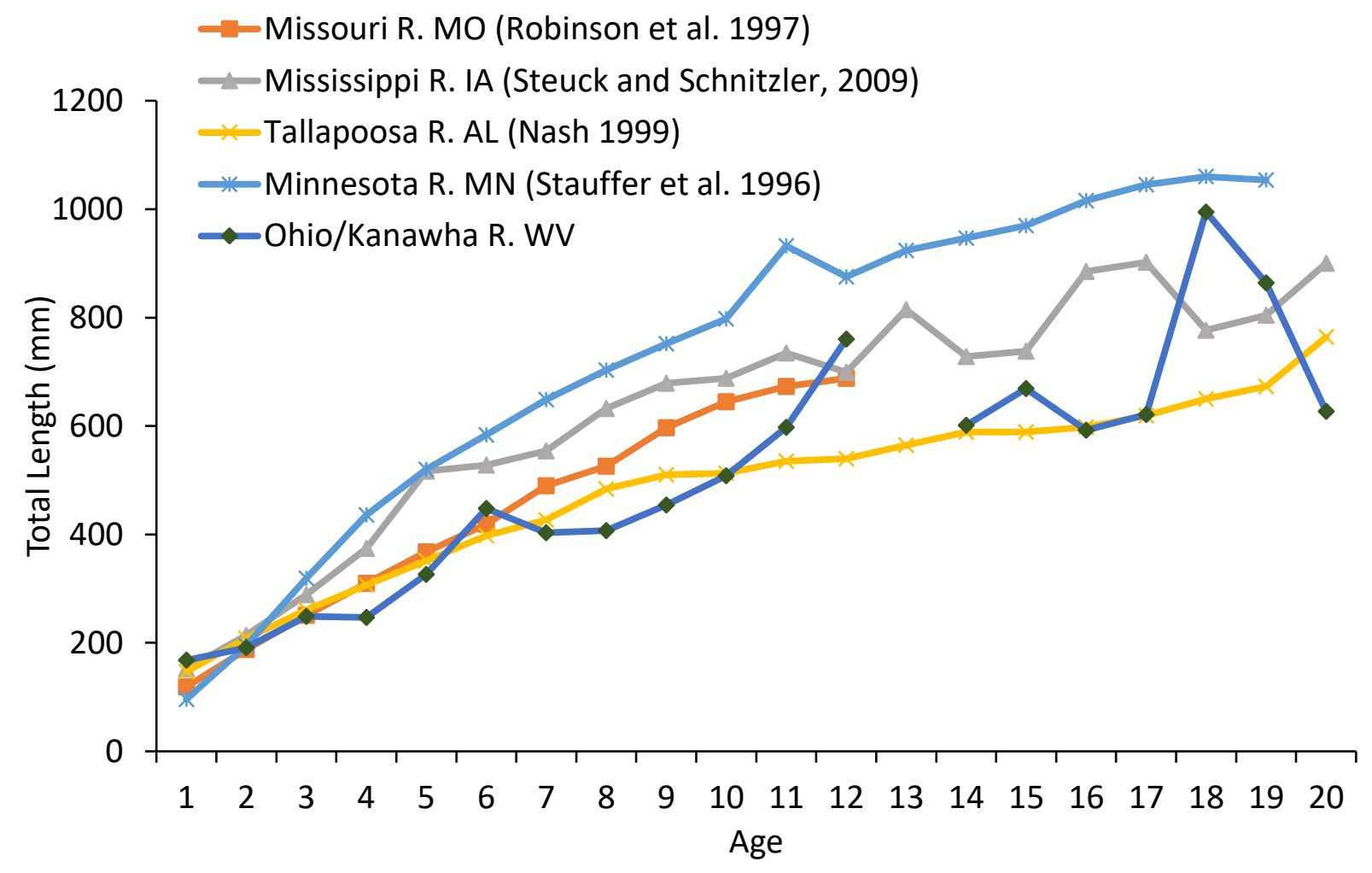

Figure 3. Mean length at age values from this study (Ohio/Kanawha R. WV) and those from published riverine Flathead Catfish growth studies within their native range. 


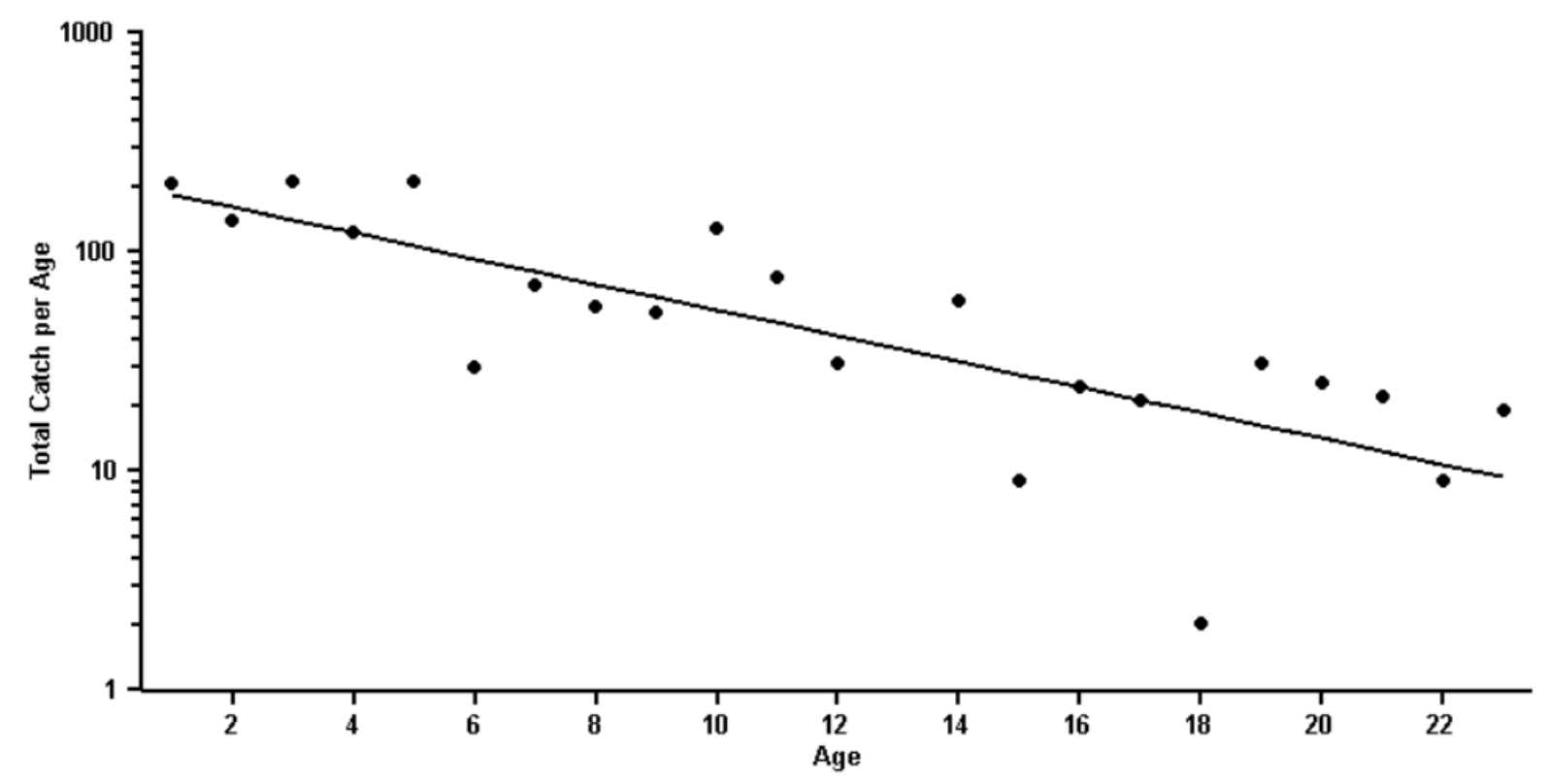

Figure 4. Catch curve using Flathead Catfish (ages 1-23) collected by electrofishing $(\mathrm{n}=1,554)$. Unaged fish were assigned ages using an age-length key (25 $\mathrm{mm}$ groups). Fish with unassigned ages were assigned the age produced from the von Bertalanffy growth function. Estimated annual mortality $=0.126, \mathrm{r}^{2}=0.63$. 